\title{
PNNL-11048
}

UC-810

Project Technical Information

RECEIVED

MAR 281996

Test Plan: Laboratory-Scale

Testing of the First Core Sample

OSTI

from Tank 102-AZ

E. V. Morrey

March 1996

Prepared for the U.S. Department of Energy under Contract DE-AC06-76RLO 1830

Pacific Northwest National Laboratory

Operated for the U.S. Department of Energy by Battelle Memorial Institute 
PNNL-11048

UC-810

Project Technical Information

\section{Test Plan: Laboratory-Scale Testing of the First Core Sample from Tank 102-AZ}

E. V. Morrey

March 1996

Prepared for

the U.S. Department of Energy

under Contract DE-AC06-76RLO 1830

Pacific Northwest National Laboratory

Richland, Washington 99352

Reprìnt of historical document PHTD-C92-05.05A, dated March, 1992. Data, formaiting, and other conventions reflect standards at the original date of printing. Technical peer reviews and editorial reviews may not have been performed. 


\title{
DISCLAIMAER
}

This report was prepared as an account of work sponsored by an agency of the United Siates Covernment. Neither the Lnited Siates Covernment nor any agency thereof, nor Eatelle Memorial Instivite, nor any of their employees, makes any Harranty, express or implied, or assumes any legalliability or responsibility for the accuracy, completeness, or.usefulness of any information, apparafus, product, or process disclosed, or represents that its use would not infringe privately ow'ned rights. Reference herein io any specinic commercial product, process, or service by irade name, irademark, manufacturer, or othenvise dues not necessarily constituve or imply its endorsement, recommendation, or favoring by the United States Government of any agency thereof, or Banelle Memorial Instivie. The views and opinions of authors expressed herein do not necessarily state or reflect those of the United States Covernment or any agency thereof.

\author{
PACIFIC NORTHWEST NATIONAL LABORATORY \\ operaied by \\ BATTELLE \\ for the \\ UNITED STATES DEPARTMENT OF ENERGY \\ under Contract DE-ACO6-76RLO 1830
}

Printed in the United Stales of America

Available to DOE and DOE contractors from the


prices available from (615) 576-5401.

Available to the public from the National Technical Information Service, U.S. Department of Commerce, 5285 Port Royal Rd., Springield, VA 22161 


\section{TABLE OF CONTENTS}

1.0 INTRODUCTION ........................ I

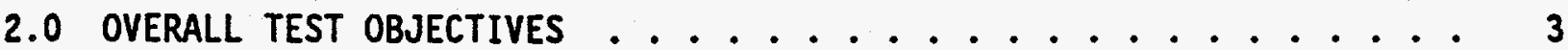

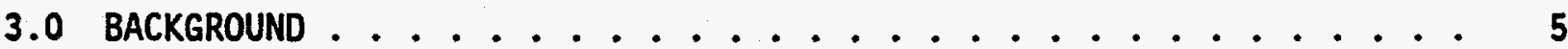

3.1 PRETREATMENT/CHARACTERIZATION PERFORMED BY DST CHARACTERIZATION PROGRAM $\ldots \ldots \ldots 5$

3.2 PREVIOUS HYDROGEN GENERATION STUDIES ......... 7

3.3 RELATIONSHIP OF RADIOACTIVE LABORATORY-SCALE TESTING TO WAPS

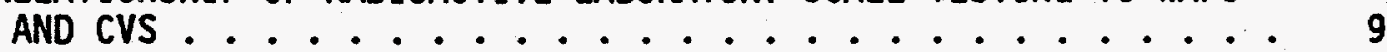

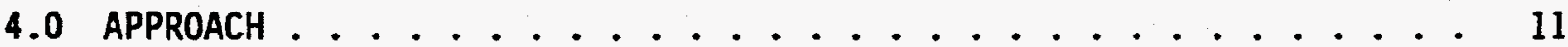

4.1 SIMULANT PREPARATION $\ldots$ II

4.2 FORMIC ACID ADDITION AND OFF-GAS ANALYSIS ........ 13

4.3 FRIT ADDITION ...................... 24

4.4 CALCINING AND VITRIFICATION ............... 24

4.5 PRODUCT TESTING .................... 26

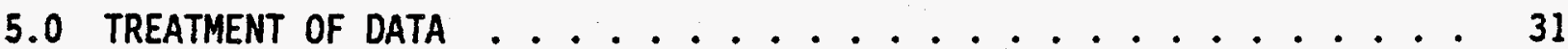

5.1 DATA REDUCTION METHODS .................... 31

5.2 EXPECTED FINAL DATA FORM ............... 32

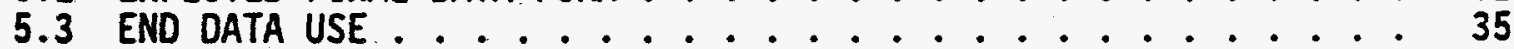

6.0 ENVIRONMENTAL SAFETY AND HEALTH (ES\&H), WASTE MANAGEMENT

REQUIREMENTS .................. 36

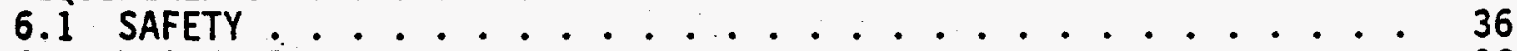

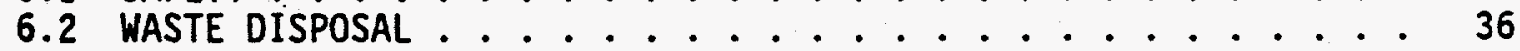

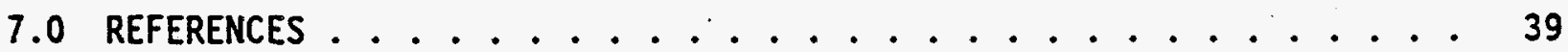

APPENDIX ......................... 40 
PHTD-C92-05.05A

\subsection{INTRODUCTION}

The primary objective of the Radioactive Process/Product Laboratory Testing (RPPLT) is to provide preliminary confirmation that the nonradioactive waste feed simulant recipe is adequate for addressing the testing needs of design, safety, waste form qualification (WFQ), and permitting of the Hanford Waste Vitrification Plant (HWVP). The testing entails processing core samples of actual radioactive high-level waste according to a laboratory-scale version of the HWVP flowsheet and testing properties of the resulting glass. A more definitive confirmation of this objective will be obtained through bench-scale testing of radioactive waste, which is planned as future work.

The purpose of this test is to produce glass from a radioactive pretreated Neutralized Current Acid Waste (NCAW) core sample taken from tank 241-AZ-102 (102-AZ) in the 200-East Area of the Hanford site. The glass composition will be formulated as a part of this test. The radioactive feed (formated slurry and melter feed) and glass will be characterized, including off-gas analysis during formating. The remaining radioactive glass will be archived to enable additional analyses at a later date, as deemed prudent by the customer. The radioactive feed and glass data from this test will be compared with available synthetic, nonradioactive feed and glass properties from this and other studies to determine the equivalence of properties. Durability data will be obtained on the radioactive and simulant glasses. incell and the simulant glass out-of-cell to allow comparison of the radioactive data to a larger database of out-of-cell simulant data and model predictions.

This PNL HWVP Technology Development (PHTD) test is an extension of a Double-Shell Tank (DST) Characterization Program study to characterize the first core sample from tank 102-AZ. The DST study has been completed and resulted in characterization and pretreatment of the core sample and characterization of the resulting washed solids. All work was performed under Technology Program Plan, "Characterization of Core Samples from DSTs 101-AZ and 102-AZ," Revision 1, June 1989. The PHTD test will utilize these washed solids samples and analyses to perform formating, frit addition, vitrification, product testing and hydrogen generation testing. The 
requirements defined in this test plan for formating of the 102-AZ core sample will supersede those defined in the DST Technology Program Plan. This PHTD test is authorized by the "Fiscal Year (FY) 1991 and 1992 Statements of Work for Applied Technology Tasks to be Performed by PHTD in Support of the HWVP Project," WHC-SP-0638 Revision $O$ and WHC-SD-HWV-SOW-002 Revision 0 . Issuance of this test plan, completion of testing, and documentation of test results will satisfy the following milestones: C92-05.05A, "Issue a test plan for laboratory feed preparation, vitrification, leach testing, and hydrogen generation testing of the first NCAW core sample from DST 102-AZ;" C92-05.05B, "Issue a letter report on hydrogen generation measurements;" and C92-05.05C, "Issue a status letter on vitrification and characterization of glass from the third NCAW core sample." A final report will be written combining results from this test $p l a n$ and from the test $p l$ an for the first two NCAW core samples (HWVP-89-IVJ0030402B, "Laboratory Vitrification of Radioactive Pretreated Neutralized Current Waste Test PIan," D. E. Larson, May 1989) to complete key milestone K969, "Issue Final Report on Radioactive Formating, Vitrification and Product Testing." 
PHTD-C92-05.05A

\subsection{OVERALL TEST OBJECTIVES}

The overall objectives of the Radioactive Process/Product Laboratory Testing (RPPLT), WBS 1.2.2.05.05, are to confirm that simulated HWVP feed and glass are representative of actual radioactive HWVP feed and $\mathrm{glass}$ and to provide radioactive leaching and glass composition data to WFQ. This study will provide data from one additional NCAW core sample (102-AZ Core 1) for these purposes. The specific objectives of this test are as follows:

- Prepare a nonradioactive simulant of 102-AZ Core 1 for direct comparison of simulant hydrogen generation rates. An adequate simulant of the core sample is not currentiy available from other HWVP tasks and is needed to understand similarities and differences between simulant and actual waste.

- Perform off-gas analysis during formic acid addition and boil-off of simulant and radioactive samples to verify that generation rates of hydrogen and other gases from simulant waste feeds are representative of the actual radioactive waste feeds. The data acquired from these analyses are intended to determine the combined effects of radiation and chemical differences between the actual waste and simulants. Further simulant and possibly radioactive studies may be necessary if the simulant behavior is not adequately representative of the core sample behavior. This work is beyond the scope of this test plan and is therefore not discussed. The hydrogen generation letter report referenced in Section 1.0 will attempt to explain causes for any off-gas differences and will propose future work to resolve the differences.

- Perform feed concentration, formic acid addition and recycle addition on the radioactive core sample and simulant and complete characterization of the formated slurries. Compare properties of the radioactive and simulant samples to each other, to results from other studies, to data in the HWVP Technical Manual (Larson 1989), and to specifications in the HWVP Technical Data Package (TDP), SD-HW-DP-001.

- Formulate, prepare and add frit to the radioactive core sample and simulant and complete characterization of the melter feed. (This laboratory-scale test uses crucibles instead of a melter system for vitrification. The formated slurry/frit mixture is referred to as "melter feed" throughout this test plan to be consistent with largerscale terminology.) Compare properties of the radioactive and simulant melter feed samples to each other, to data in the technical manual, and to specifications in the TDP.

- Perform vitrification of the radioactive and simulant melter feed and complete characterization of the glass. Glass composition data is 
needed for preliminary supporting information for eventual input to the WQR, possible input to the Feed Processability Assessment, and CVS models and normalized release rate calculations.

- Perform PCT leach test on radioactive and simulant glass for validation of the CVS models.

- Provide a qualitative assessment of the adequacy of analytical techniques for characterization of HWVP process solutions and glass. 
PHTD-C92-05.05A

\subsection{BACKGROUND}

The subject core sample of this test plan, 102-AZ Core 1 , is the third NCAW core sample to be processed through the HWVP process steps on a laboratory-scale. The first two cores, 101-AZ Core 1 and 2, have been vitrified and are undergoing product testing. Partial preliminary results have been included in year-end status reports (Allen 1990; Elliott, Morrey and Tingey 1991).

\subsection{PRETREATMENT/CHARACTERIZATION PERFORMED BY DST CHARACTERIZATION PROGRAM}

A flow diagram representing the process testing for 102-AZ Core 1 is shown in Figure 3.1. The relationship between the laboratory process steps and the plant equipment operations are provided. Core sample washing and washed solids characterization steps have already been completed under the DST Characterization Project, and are included in the figure for completeness.

Following complete characterization of the as-received core sample, the composite slurry was processed through a laboratory-scale, B-Plant pretreatment process. The core sample was pretreated prior to a change in the pretreatment baseline to in-tank washing. Based on the B-Plant flowsheet represented in Figure 3.1, the waste entering B-P1ant is expected to contain 20 vol\% settled solids, and ferric nitrate is added to promote settling. However, in the case of this core sample, the composite core contained only a small amount of liquid and was too viscous to settle. Nevertheless, to simulate the B-Plant process, ferric nitrate was added to the remaining composite core waste and washing of the composite core with the added ferric nitrate was performed (Gray, Peterson, Scheele and Tingey 1990).

Washing was performed by adding deionized water (DIW) to the composite core in a volume ratio of 3 parts DIW to 1 part composite core. The mixture was thoroughly stirred for $1 \mathrm{hr}$ and then allowed to settle for $23.5 \mathrm{hrs}$. As much supernate as possible was removed without disturbing the settled solids, and a second wash was performed by again adding DIW to the settled solids in a 




Figure 3.1 HWVP Test Plan for the First Core Sample from 102-AZ 
$3: 1$ volume ratio. The mixture was stirred for $1 \mathrm{hr}$ and then allowed to settle for $22 \mathrm{hrs}$. Again, as much supernate as possible was removed without disturbing the settled solids.

Sodium hydroxide and sodium nitrite were added to the washed solids to meet tank specifications (Gibson and Landeene 1987). These two chemicals were added to produce final concentrations of $-0.04 \underline{M}$ each. Physical, chemical, radiochemical, and rheological properties of the pretreated waste were measured. The measured composition of the washed solids sample is provided in Tables 3.1 and 3.2.

\subsection{PREVIOUS HYDROGEN GENERATION STUDIES}

Formic acid is added during the preparation of radioactive wastes for vitrification to obtain an acceptable glass redox potential and improve the rheology in the waste slurry. Denitration and formic acid decomposition may be secondary effects of the use of formic acid in these waste slurries. The reaction of formic acid with nitric acid is well known, and its applications for denitration of radioactive wastes has been studied (Cecille and Halasovich 1986). Most of the studies have been concerned with reactions under acidic conditions, and the process steps in the HWVP system will occur under basic to weakly acidic conditions. The composition of the Hanford radioactive wastes also differ from the compositions used in the previous studies. Under these different conditions, the mechanisms and kinetics of these reactions are likely to differ significantly (Longstaff and Singer 1954). A number of differences are expected between the radioactive data and the simulant data. These differences are as follows: 1) radiolysis is predicted to contribute to $\mathrm{H}_{2}$ generation through decomposition of $\mathrm{H}_{2} \mathrm{O}$ and organics; 2) cold simulants do not contain $\mathrm{U}, \mathrm{PU}$, and $\mathrm{Th}$, which may act as catalysts in $\mathrm{H}_{2}$ generation; and 3 ) radiolysis may change the reaction mechanisms leading to release of reduced nitrogen species in the off-gas.

The presence of $\mathrm{H}_{2}, \mathrm{NH}_{3}, \mathrm{NO}_{x}, \mathrm{~N}_{2} \mathrm{O}$, and $\mathrm{CO}_{2}$ in off-gases released during formating of NCAW feed simulants has been reported (Wiemers, Anderson and Peterson 1987; Wiemers 1990). The presence of $\mathrm{H}_{2}, \mathrm{NO}, \mathrm{NO}_{2}, \mathrm{~N}_{2} \mathrm{O}$, and $\mathrm{CO}_{2}$ during formic acid addition in the IDMS tests at Westinghouse Savannah River Company 
IABLE 3.1. Comparison of HWVP Reference Feed Composition to 102-AZ, Core \#1

\begin{tabular}{|c|c|c|c|c|}
\hline & \begin{tabular}{|c|}
$102-A Z$ \\
Core \#1 (a) \\
moles E/L of feed
\end{tabular} & $\begin{array}{l}\text { NCAW SRAT Ref. Feed } \\
\text { FY91 Revision (a) } \\
\text { moles Element/L of feed }\end{array}$ & $\begin{array}{c}102-A Z \\
\text { Core } \# 1 \text { (b) } \\
\text { wt\% (feed oxide) }\end{array}$ & $\begin{array}{l}\text { NCAW SRAT.Ref. Feed } \\
\text { FY91 Revision (c) } \\
\text { wt\% (feed oxide) }\end{array}$ \\
\hline Ag2O & 1.78E-03 & $1.29 E-03$ & $1.58 E-01$ & $1.20 E-01$ \\
\hline $\mathrm{A} / 203$ & $5.48 E-01$ & 2.22E-01 & $2.14 E+01$ & $9.04 E+00$ \\
\hline As203 & $<2.16$ E-03 & 5.38E-07 & $<1.64 E-01$ & 4.25E-05 \\
\hline $\mathrm{B2O3}$ & $<2.27 E-02$ & 2.06E-04 & $<6.06 E-01$ & 5.75E-03 \\
\hline $\mathrm{BaO}$ & $1.16 E-03$ & $1.43 E-03$ & $1.36 E-01$ & $1.76 E-01$ \\
\hline$B e 0$ & 5.34E-04 & $5.04 E-03$ & 1.02E-02 & 1.01E-01 \\
\hline $\mathrm{CaO}$ & 2.28E-02 & $1.76 E-02$ & 9.82E-01 & 7.91E-01 \\
\hline $\mathrm{CdO}$ & 3.73E-02 & 2.94E-02 & $3.67 E+00$ & $3.02 E+00$ \\
\hline $\mathrm{CeO} 2$ & 2.08E-03 & 4.39E-03 & 2.74E-01 & 6.05E-01 \\
\hline $\mathrm{Co2O} 3$ & $<1.93 E-02$ & & $<1.23 E+00$ & \\
\hline $\mathrm{Cr} 2 \mathrm{O} 3$ & $8.14 E-03$ & $4.30 E-03$ & $4.74 E-01$ & 2.62E-01 \\
\hline $\mathrm{CuO}$ & 2.53E-03 & 3.85E-03 & $1.54 E-01$ & 2.45E-01 \\
\hline Dy203 & 7.95E-05 & $6.98 E-07$ & $1.14 E-02$ & $1.04 E-04$ \\
\hline $\mathrm{Fe} 2 \mathrm{O} 3$ & $6.48 E-01$ & 4.42E-01 & $3.96 E+01$ & $2.82 E+01$ \\
\hline $\mathrm{K} 2 \mathrm{O}$ & $<2.50$ E-02 & 5.21E-03 & $<9.02 E-01$ & 1.96E-01 \\
\hline La2O3 & 9.11E-03 & 5.01E-03 & $1.14 E+00$ & 6.53E-01 \\
\hline 120 & 8.98E-03 & 5.92E-06 & 1.03E-01 & $1.84 E-04$ \\
\hline $\mathrm{MgO}$ & 1.11E-02 & $6.25 E-03$ & 3.42E-01 & 2.02E-01 \\
\hline $\mathrm{MnO} 2$ & 1.47E-02 & $3.08 E-02$ & 9.76E-01 & $2.14 E+00$ \\
\hline $\mathrm{MoO3}$ & $<3.98 E-04$ & 4.85E-03 & $<4.39 E-02$ & 5.59E-01 \\
\hline $\mathrm{Na2O}$ & 5.10E-01 & $8.64 E-01$ & $1.21 E+01$ & $2.14 E+01$ \\
\hline $\mathrm{Nd} 2 \mathrm{O} 3$ & 6.70E-03 & $4.29 E-03$ & 8.64E-01 & 5.78E-01 \\
\hline $\mathrm{NiO}$ & 4.11E-02 & 3.85E-02 & $2.35 E+00$ & $2.30 E+00$ \\
\hline $\mathrm{P} 2 \mathrm{O} 5$ & 3.82E-02 & $1.53 E-02$ & $2.08 E+00$ & 8.72E-01 \\
\hline $\mathrm{PbO} 2$ & $2.02 E-03$ & 3.66E-03 & 3.71E-01 & 7.00E-01 \\
\hline PdO & $\mathrm{NM}$ & 1.23E-03 & NM & $1.20 \mathrm{E}-01$ \\
\hline $\mathrm{ReO} 2$ & $2.16 E-04$ & & $3.61 E-02$ & \\
\hline Rh203 & $1.25 E-03$ & 1.02E-03 & 1.22E-01 & 1.04E-01 \\
\hline RuO2 & 1.34E-03 & 3.77E-03 & 1.37E-01 & $3.80 E-01$ \\
\hline $\mathrm{Sb} 2 \mathrm{O} 3$ & $<4.32 E-03$ & $5.00 E-05$ & $<4.82 E-01$ & $5.88 E-03$ \\
\hline $\mathrm{SeO} 2$ & $<2.84 E-03$ & $1.78 E-04$ & $<2.42 E-01$ & $1.59 E-02$ \\
\hline $\mathrm{SiO} 2$ & 4.83E-02 & 8.38E-02 & $2.22 E+00$ & $4.03 E+00$ \\
\hline Sro & $1.02 E-03$ & $1.43 E-03$ & 8.12E-02 & 1.19E-01 \\
\hline TeO2 & $1.55 E-03$ & 7.77E-04 & $1.89 E-01$ & $1.01 E-01$ \\
\hline ThO2 & $<1.14 E-03$ & & $\leq 2.30 E-01$ & \\
\hline TIO2 & 5.91E-04 & $1.02 E-02$ & 3.62E-02 & $6.52 E-01$ \\
\hline 71203 & $<1.14 E-02$ & & $<1.99 E+00$ & \\
\hline U308 & 1.41E-02 & 2.11E-02 & $3.03 E+00$ & $4.74 E+00$ \\
\hline V2O3 & $4.20 E-04$ & & 2.41E-02 & \\
\hline Zno & 1.17E-03 & 5.13E-03 & 7.30E-02 & 3.34E-01 \\
\hline ZrO2 & $6.72 E-02$ & $1.53 E-01$ & $6.34 E+00$ & $1.51 E+01$ \\
\hline
\end{tabular}

Elements shown in this table are those measured by ICP. Radiochemical results are not shown.

(a) Data assumes $125 \mathrm{~g}$ WO/L (ICP concentrations were adjusted using wt\% oxide measurement).

(b) Data is normalized to $100 \%$ (normalized to ICP/IC data).

NM $=$ Not measured

(c) Column does not total $100 \%$ because some minor reference feed components have been omitted 
TABLE 3.2. Comparison of HWVP Reference Feed Anion Composition to 102-AZ, Core \#1

\begin{tabular}{|l|c|c|c|c|}
\cline { 2 - 6 } \multicolumn{1}{c|}{} & $\begin{array}{c}102-A Z \\
\text { Core \#1 (a) } \\
\text { moles E/L of feed }\end{array}$ & $\begin{array}{c}\text { NCAW SRAT Ref. Feed } \\
\text { FY91 Revision (a) } \\
\text { moles E/L of feed }\end{array}$ & $\begin{array}{c}102-A Z \\
\text { Core \#1 (b) } \\
\text { g/100 g Oxide }\end{array}$ & $\begin{array}{c}\text { NCAW SRAT Ref. Feed } \\
\text { FY91 Revision (b) } \\
\text { g/100 g Oxide }\end{array}$ \\
\hline F & $4.88 E-03$ & $6.38 E-03$ & $7.10 E-02$ & $9.70 E-02$ \\
NO2 & $6.93 E-04$ & $1.06 E-02$ & $1.83 E-02$ & $3.00 E-01$ \\
NO3 & $5.16 E-02$ & $4.35 E-01$ & $1.82 E+00$ & $1.60 E+01$ \\
\hline PO4 (c) & $1.39 E-02$ & $1.16 E-01$ & $6.59 E-01$ & $5.75 E+00$ \\
SO3 & $2.57 E-03$ & $1.03 E-03$ & $1.87 E-01$ & $1.03 E-03$ \\
TIC (CO3) & $8.30 E-03$ & $1.02 E-02$ & $5.09 E-01$ & $6.55 E-01$ \\
TOC & $2.89 E-01$ & $1.25 E-01$ & $1.33 E+01$ & $6.00 E+00$ \\
\hline
\end{tabular}

(a) Assumes $125 \mathrm{~g}$ WO/L (IC \& Carbon concentrations were adjusted using wt\% oxide measurement).

(b) Calculations are based on normalizing nonvolitale oxides measured from ICP and IC to $100 \%$.

(c) The PO4 measurement in this table is soluble PO4 and is part of the total P shown in Table 3.1.

(d) Calculation is not performed since the composition of the organic carbon is not quantified.

(WSRC) were also observed (Hutson, 1991). Similar gases were reported for the HWVP pilot scale melter off-gas (Goles and Nakaoka 1990).

The addition of formic acid to two core samples of NCAW waste has been completed. The $\mathrm{pH}$ and temperature during formic acid addition were monitored, but no attempt was made to monitor the gas generation during this process. Limited chemical and radiochemical analyses of the waste prior to and following the addition of formic acid were performed (Allen 1990; Elliott, Morrey and Tingey 1991).

\subsection{RELATIONSHIP OF RADIOACTIVE LABORATORY-SCALE TESTING TO WAPS AND CVS}

The Department of Energy has established Waste Acceptance Preliminary Specifications (WAPS), June 1991 draft, governing the characterization, control, and documentation of high-level nuclear waste glass produced by a vitrification plant. These specifications are generally accepted as representative of the requirements that will be established formally for all waste glass producers including HWVP. Specification 1.3 requires that glass 
be at least as durable as the DWPF Environmental Assessment (EA) glass as determined by the Product consistency Test (PCT). WAPS 1.3 allows that the test result may be predicted rather than measured from actual production glass if an acceptable means for this is provided and defended. The WAPS specification is subject to change.

Under the auspices of the PHTD Project, an empirical relationship is being determined between the composition and durability of simulated highlevel nuclear waste $\mathrm{glasses.} \mathrm{The} \mathrm{relationship} \mathrm{has} \mathrm{been} \mathrm{determined} \mathrm{as} \mathrm{part} \mathrm{of}$ the "Composition Variability Study" (CVS). Glasses of various compositions have been and are being prepared for this statistically-designed study, and their properties measured. The CVS study includes two static leach tests for each of the glasses in the test matrix: the Materials Characterization Center (MCC-1) 28-day test and the 7-day Product Consistency Test (PCT). The leach test results were used to fit empirical models.

The models are currently being developed for Hanford DST wastes including pretreated NCAW using simulated nonradioactive glass. The models will be validated as part of the CVS, using results from simulated glasses. To validate the model for application to radioactive glass, radioactive waste data and comparisons are necessary. Due to unavoidable differences between leach testing in a hot cell and CVS leach testing (e.g., CVS Teflon leach containers cannot be used in the hot cel1), the hot-cell results may not be predictable by the models. Therefore, the validation process may require three step process: 1) relate in-cell radioactive data to in-cell simulant data, 2) relate in-cell simulant data to out-of-cell simulant data, and 3) relate out-of-cell simulant data to model predictions. 


\subsection{APPROACH}

The limited amount of washed solids (approximately $20 \mathrm{~g}$ of oxides) resulting from a core sample and the need to produce sufficient glass for product testing precludes a conventional test matrix. In the case of the core sample testing, a single set of data is achieved for each step of the HWVP process. As a part of this study, the washed solids sample from 102-AZ Core 1 will be processed through each of the operations shown in figure 3.1 under the HWVP portion of Laboratory Operations.

A primary objective of the RPPLT is to confirm that simulated HWVP feed is representative of radioactive HWVP feed. To provide a direct comparison of simulated to actual waste, a chemical/physical simulant of 102-AZ Core 1 will be prepared and processed through the same process and product testing as the core sample. Glass produced from the simulant will be leach tested both in the hot cell under the same conditions as the radioactive samples and in the CVS laboratory.

\subsection{SIMULANT PREPARATION}

The objective of simulant preparation is to prepare a simulant with representative chemical and physical properties to the radioactive sample. Simulant preparation will be performed using a method developed to simulate the history of the waste processing. In general, the method consists of adding constituents as nitrates and co-precipitating them into hydroxides. The chemical composition of the waste can be matched with good precision (within analytical certainty) and the resulting physical properties are expected to be representative of the actual waste (per conversation with K.D. Wiemers). This method is also consistent with simulant preparation performed for the laboratory-scale redox/rheology testing (Wiemers 1991) and large-scale testing at PNL, SRL, and KfK.

Major components including aluminum, iron, manganese, nickel and zirconium will be precipitated from nitrate solutions and washed to remove the sodium and nitrate prior to adding the minor components. The insoluble minor 
PHTD-C92-05.05A

components (i.e., Ag, Cd, Ce, Cr, La, Li, Mg, Nd, Pb, Pd, Rh, Ru, Si, Te, Ti, and $\mathrm{Zn}$ ) will be co-precipitated, washed and blended with the major components. Certain soluble or slightly soluble minor components (i.e., B, Ba, Ca, Cs, Cu, $\mathrm{Na}$, and $\mathrm{Sr}$ ) will be added directly as oxides, hydroxides, fluorides or sulfates to the major/minor mixture. Sodium will be added in multiple forms in order to match the carbonate and anion (i.e., $\mathrm{F}, \mathrm{Cl}, \mathrm{NO}_{2}, \mathrm{NO}_{3}, \mathrm{PO}_{4}, \mathrm{OH}$, and $\mathrm{SO}_{4}$ ) concentrations in the waste.

Special care will be taken to match noble metals (Pd, Rh, Ru), nitrate, nitrite, carbonate, acid/base neutralization capacity ( 1 imited sample quantity may prevent this measurement), magnesium, iron, and alkal ine earth concentrations as they may have an affect on hydrogen generation. The nine modeled CVS constituents (i.e., $\mathrm{Al}, \mathrm{B}, \mathrm{Ca}, \mathrm{Fe}, \mathrm{Li}, \mathrm{Mg}, \mathrm{Na}, \mathrm{Si}$, and $\mathrm{Zr}$ ) will also be matched as closely as possible as they affect glass properties.

A certain amount of error is anticipated in matching the simulant to the core sample due to analytical uncertainty in the simulant and radioactive sample. The hydrogen generation reactions are believed to be highly influenced by rhodium concentration. Small differences in rhodium concentration may impact the comparability of the results. If the results are not the same for radioactive and simulant samples, it does not necessarily mean that the simulants being used are not representative of actual waste. This type of result would encourage further investigation.

The FY 1992 SOW requires that noble metals concentrations be verified in 102-AZ core 1 prior to initiation of testing, which in principle is appropriate since hydrogen generation is dependent on noble metals concentration (i.e., rhodium). However, there is no readily available technique for obtaining this verification on fully radioactive samples. The analysis of core sample washed solids by $X$-ray Fluorescence (XRF) is not practical due to dose. The radioactive ICP - Mass Spectrometer (MS) is not currently available for radioactive samples and preparation procedure development (closed system $\mathrm{HF} / \mathrm{HNO}_{3}$ boric acid digestion) for hot cell samples is required. Verification of the noble metals concentration by ICP-MS will be performed when the capability is available. 
The current noble metals measurements in the core sample are from sodium peroxide and potassium hydroxide fusions followed by Inductively coupled Plasma - Atomic Emission Spectroscopy (ICP-AES), which yields ruthenium and rhodium measurements but not palladium (see Table 3.1). The measured ruthenium concentration is expected to be 3-4 times lower than the actual concentration, due to ruthenium volatility in the analytical preparation step. This is supported by the ruthenium to rhodium ratio, which is not consistent with fission yields (see comparison of actual to feed specification). The best available information is that the noble metals in the core sample are near nominal concentrations. This assumption will be used in simulant preparation. If need be, the simulant portion of the test can be repeated after verified noble metals results are available.

\subsection{FORMIC ACID ADDITION AND OFF-GAS ANALYSIS}

\subsubsection{Experimental Apparatus and Set-Up}

The experimental apparatus and set-up for the formic acid addition and off-gas analysis is shown in Figure 4.1. Formating and off-gas analysis of the radioactive waste will be performed in the 325-B analytical hot cell facility. Off-gas analytical equipment will be contained in an existing hood adjacent to hot cell \#4. Frit addition and concentration adjustments (e.g. initial boil-off) will be performed in 325-A hot cell facility. The temperature of the waste slurry will be controlled to $95 \pm 3^{\circ} \mathrm{C}$ using a temperature controller connected to a thermocouple inserted between the reaction vessel and the heating mantel or in the heating bath. A Variac will be used between the power source and temperature controller to reduce fluctuations in temperature. The actual temperature will be read from a calibrated digital thermometer connected to a calibrated thermocouple inserted in the waste slurry. The $\mathrm{pH}$ will be monitored with a temperature compensated $\mathrm{pH}$ meter. Throughout the formic acid addition the sample will be stirred to achieve uniform particle movement and mixing. The formic acid addition line will be placed below the surface of the waste slurry to assure good mixing of the formic acid. Visual observations of foaming will be recorded; and if possible, a rough quantitative measure will be made using graduated markings 


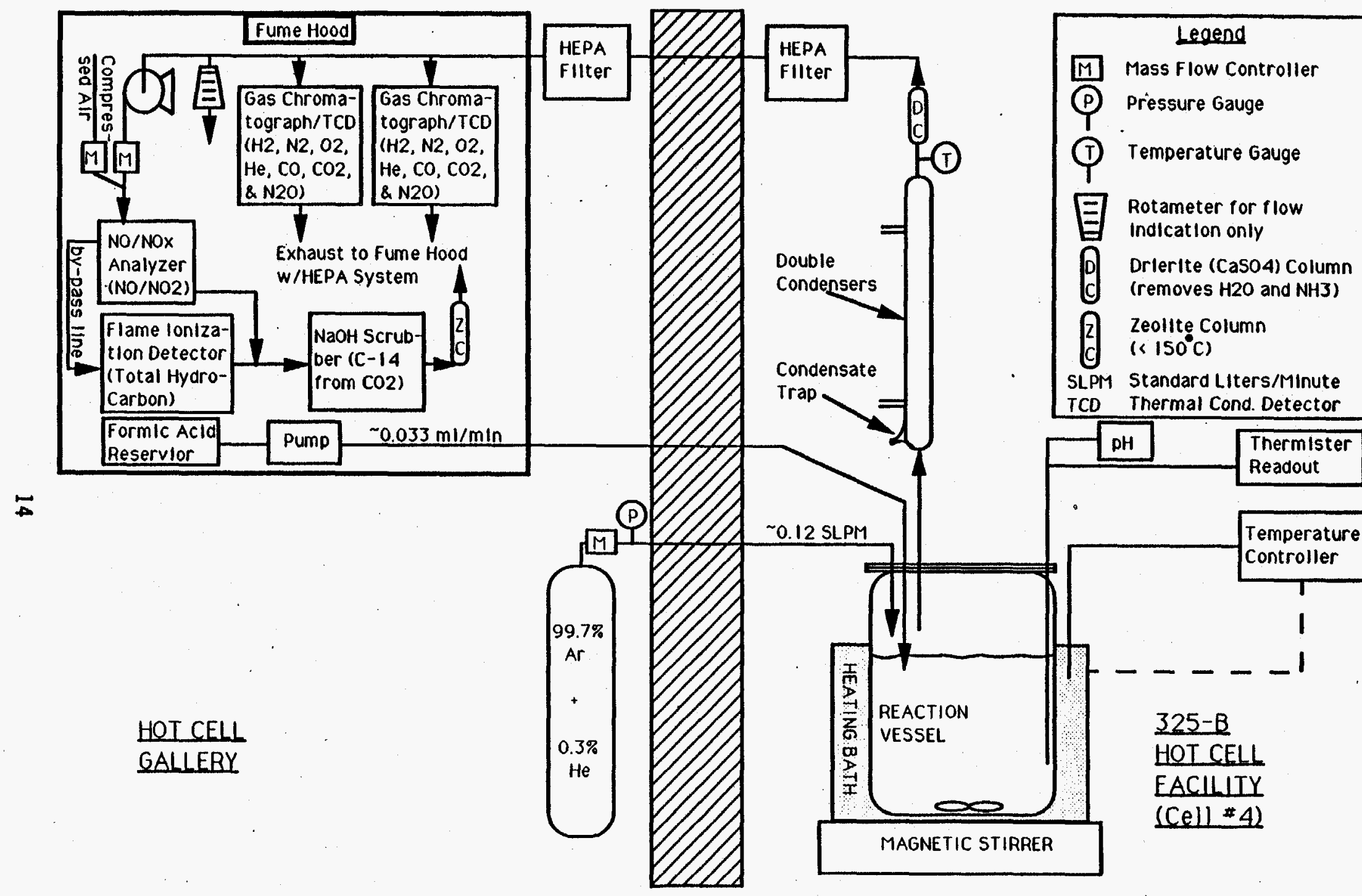

FIGURE 4.1 SETUP FOR OFFGAS MEASUREMENT SYSTEM 
PHTD-C92-05.05A

on the reaction vessel. A double condenser will be used to minimize the amount of condensable vapors entering the off-gas analysis system. The condensate from the condensers will be collected in a condensate trap and will be analyzed at the completion of the test.

The gas generation rate will be measured by using a tracer gas and calculating the dilution of the tracer upon mixing with the off-gases. The tracer gas will be helium and will be supplied with the carrier gas which is argon. The off-gases will be swept through the system with a controlled volume of carrier gas. The flow rate of the carrier gas will be set to achieve approximately 3 volumes of sweep gas/volume of head space for every sampling period (i.e., one minute).

The mixed gases will pass through a double HEPA filter system before being sampled by the off-gas analysis equipment. The analyzers to be utilized include two gas chromatographs (GCS) with thermal conductivity detectors (TCDs), a flame ionization detector (FID), and a NO/NOX analyzer. A zeolite column, a drierite column and an $\mathrm{NaOH}$ scrubber will also be utilized to collect ${ }^{129} \mathrm{I}, \mathrm{NH}_{3}$, and ${ }^{14} \mathrm{C}$ from $\mathrm{CO}_{2}$ respectively for recovery and measurement at the conciusion of a test. Exhaust from the analyzers and the remaining gas stream will be exhausted to the fume hood, which passes through HEPA filters into the building ventilation system.

The GCS will be configured in one of several ways depending on results of the simulant testing. If a rapid measurement interval is necessary to characterize the $H_{2}$ peak, the first $G C$ will be setup to analyze only for $H_{2}$ and $\mathrm{He}$, and the second $\mathrm{GC}$ will be used to monitor the full range of off-gases as indicated in Figure 4.1. If a moderate measurement interval is required, both GCs will be set up for the full range of components, but with measurements offset from each other in time (one minute apart). Additionally, the units may be setup at different detection sensitivities to assure that all components are detectable and measurable.

\subsubsection{Test Conditions}

The $\mathrm{pH}$ of the washed solids will be measured prior to testing. If the $\mathrm{pH}$ is above 10, no further additions of $\mathrm{NaOH}$ will be made. As can be noted by 
Table 3.2, the nitrate and nitrite concentrations of the core sample are nearly an order of magnitude lower than the FY9l feed specification. This is due to three reasons as follows: 1) the nitrate and nitrite concentrations of the unwashed core sample were several times lower than the two previous NCAW core samples, 2) cesium recycle (containing $\mathrm{CsNO}_{3}$ and $\mathrm{NaNO}_{3}$, the latter coming from neutralization of nitric acid stripping agent) has not be added to the core sample as will be done in the plant, and 3) the feed specification includes conservative (maximum value) assumptions relative to nitrate and nitrite additions during pretreatment and storage.

Due to uncertainties in the pretreatment and interim storage plans for NCAW feed to HWVP, estimating the nitrate and nitrite additions is not a straightforward problem. For example, the cesium recycle may not be recycled in a continuous manner. The first feed batches may have no recycle and later batches may have several times the nominal. In lieu of a clear pretreatment scenario, $\mathrm{NaNO}_{2}, \mathrm{CsNO}_{3}$ and $\mathrm{NaNO}_{3}$ additions will be made to the core sample to match the FY91 pretreated NCAW base case for cesium, nitrate and $60 \%$ of nominal nitrite as closely as possible. The $60 \%$ of nominal nitrite is similar to test 3.2 performed by K. D. Wiemers (Wiemers, Langowski and Powel1 1991) and is more realistic than 100\% nominal nitrite. Making these additions will simulate a realistic case and will allow a comparison with results from Wiemers. The expected core sample composition after $\mathrm{NaNO}_{2}, \mathrm{CsNO}_{3}$, and $\mathrm{NaNO}_{3}$ additions is provided in Tables 4.1 and 4.2 .

The washed solids sample will be concentrated, as necessary; to achieve $125 \pm 5 \mathrm{~g}$. TO/L of sample. The density, wt\% solids, and wt\% oxides of the sample will be determined with methods described in PNL technical procedure PNL-ALO-501.

The sample will then be divided into two equal portions for formating and off-gas analyses. The resulting batch sizes will be approximately $80 \mathrm{~m}$ each. Dividing the sample into two batches provides a measure of protection in case the test needs to be repeated. It also provides for a measure of repeatability, if both tests are successful. 
PHTD-C92-05.05A

\begin{tabular}{|c|c|c|c|c|}
\hline & $\begin{array}{c}102-A Z \\
\text { Core } \# 1 \text { (a) } \\
\text { moles } E / L \text { of feed }\end{array}$ & \begin{tabular}{|l|} 
NCAW SRAT Ref. Feed \\
FY91 Revision (a) \\
moles Element/L of feed
\end{tabular} & $\begin{array}{c}102-A Z \\
\text { Core } \# 1 \text { (b) } \\
w \% \text { (feed oxide) }\end{array}$ & $\begin{array}{c}\text { NCAW SRAT Ref. Feed } \\
\text { FY91 Revision (C) } \\
\text { wt\% (feed oxide) }\end{array}$ \\
\hline Ag2O & $1.63 E-03$ & $1.29 \mathrm{E}-03$ & 1.45E-01 & $1.20 \mathrm{E}-01$ \\
\hline Al2O3 & 5.01E-01 & $2.22 E-01$ & $1.96 E+01$ & $9.04 E+\infty 0$ \\
\hline As2O3 & $<1.98 E-03$ & $5.38 E-07$ & $<1.50 \mathrm{E}-01$ & $4.25 E-05$ \\
\hline $\mathrm{B2O3}$ & $<2.08 E-02$ & 2.06E-04 & $<5.54 E-01$ & 5.75E-03 \\
\hline $\mathrm{BaO}$ & $1.06 E-03$ & $1.43 E-03$ & 1.25E-01 & $1.76 \mathrm{E}-01$ \\
\hline $\mathrm{BeO}$ & 4.89E-04 & $5.04 E-03$ & $9.36 E-03$ & 1.01E-01 \\
\hline $\mathrm{CaO}$ & 2.09E-02 & $1.76 E-02$ & 8.98E-01 & $7.91 \mathrm{E}-01$ \\
\hline CdO & 3.41E-02 & 2.94E-02 & $3.35 E+\infty 0$ & $3.02 E+00$ \\
\hline $\mathrm{CeO2}$ & $1.90 E-03$ & 4.39E-03 & 2.51E-01 & 6.05E-01 \\
\hline $\mathrm{CO} 2 \mathrm{O} 3$ & $<1.77 E-02$ & & $<1.12 E+00$ & \\
\hline $\mathrm{C} 2 \mathrm{O3}$ & 7.44E-03 & $4.30 E-03$ & 4.33E-01 & 2.62E-01 \\
\hline Cs2O & $5.32 E-03$ & $5.32 E-03$ & 5.74E-01 & 6.05E-01 \\
\hline CuO & 2.32E-03 & $3.85 E-03$ & $1.41 E-01$ & 2.45E-01 \\
\hline Dy203 & 7.28E-0.5 & 6.98E-07 & 1.04E-02 & 1.04E-04 \\
\hline $\mathrm{Fe} 2 \mathrm{O} 3$ & 5.93E-01 & 4.42E-01 & $3.62 E+01$ & $2.82 E+01$ \\
\hline $\mathrm{K} 20$ & $<2.29 E-02$ & 5.21E-03 & $<8.25 E-01$ & $1.96 E-01$ \\
\hline La2O3 & $8.34 E-03$ & 5.01E-03 & $1.04 E+00$ & 6.53E-01 \\
\hline Li2O & 8.21E-03 & 5.92E-06 & 9.40E-02 & $1.84 E-04$ \\
\hline $\mathrm{MgO}$ & 1.01E-02 & $6.25 E-03$ & 3.13E-01 & 2.02E-01 \\
\hline MnO2 & 1.34E-02 & $3.08 E-02$ & 8.93E-01 & 2.14E+00 \\
\hline $\mathrm{MoO3}$ & $<3.64 E-04$ & 4.85E-03 & $<4.01 E-02$ & 5.59E-01 \\
\hline Na2O & $7.84 E-01$ & $8.64 E-01$ & $1.86 E+01$ & $2.14 E+01$ \\
\hline $\mathrm{Nd} 2 \mathrm{O} 3$ & 6.13E-03 & 4.29E-03 & 7.90E-01 & 5.78E-01 \\
\hline NiO & 3.76E-02 & $3.85 E-02$ & $2.15 E+00$ & $2.30 E+00$ \\
\hline P2O5 & 3.49E-02 & 1.53E-02 & $1.90 E+00$ & $8.72 E-01$ \\
\hline $\mathrm{PbO} 2$ & $1.85 E-03$ & $3.66 E-03$ & 3.39E-01 & 7.00E-01 \\
\hline$\overline{P d O}(d)$ & $1.38 E-03$ & 1.23E-03 & 1.29E-01 & $1.20 \mathrm{E}-01$ \\
\hline $\mathrm{ReO} 2$ & $1.98 E-04^{\circ}$ & & 3.30E-02 & \\
\hline Rh2O3 & $1.14 E-03$ & $1.02 E-03$ & 1.11E-01 & 1.04E-01 \\
\hline RuO2 (d) & 4.23E-03 & 3.77E-03 & 4.31E-01 & 3.80E-01 \\
\hline $\mathrm{Sb} 2 \mathrm{O} 3$ & $<3.95 E-03$ & $5.00 E-05$ & $<4.41 E-01$ & $5.88 \mathrm{E}-03$ \\
\hline SeO2 & $<2.60 \mathrm{E}-03$ & $1.78 E-04$ & $<2.21 E-01$ & 1.59E-02 \\
\hline $\mathrm{SiO}_{2}$ & 4.42E-02 & 8.38E-02 & $2.03 E+00$ & $4.03 E+00$ \\
\hline Sro & 9.36E-04 & $1.43 E-03$ & 7.43E-02 & 1.19E-01 \\
\hline TeO2 & 1.41E-03 & 7.77E-04 & 1.73E-01 & 1.01E-01 \\
\hline ThO2 & $<1.04 E-03$ & & $<2.10 E-01$ & \\
\hline TiO2 & 5.4tE-04 & 1.02E-02 & $3.31 E-02$ & $6.52 E-01$ \\
\hline $\mathrm{T} 2 \mathrm{O} 3$ & $<1.04 E-02$ & & $<1.82 E+00$ & \\
\hline U308 & 1.29E-02 & 2.11E-02 & 2.77E +00 & 4.74E + 00 \\
\hline $\mathrm{V} 203$ & 3.85E-04 & & 2.21E-02 & \\
\hline Zno & $1.07 E-03$ & 5.13E-03 & $6.68 E-02$ & 3.34E-01 \\
\hline $\mathrm{ZrO} 2$ & 6.14E-02 & 1.53E-01 & $5.80 \mathrm{E}+00$ & $1.51 E+01$ \\
\hline
\end{tabular}

Elements shown in this table are those measured by ICP. Radiochemical results are not shown.

(a) Data assumes $125 \mathrm{~g}$ WO/L (ICP concentrations were adjusted using wt\% oxide measurement).

(b) Data is normalized to $100 \%$ (normalized to $\mathrm{ICP} / \mathrm{IC}$ data). $\quad N M=$ Not measured

(c) Column does not total $100 \%$ because some minor reference feed components have been omitted

(d) Pd \& Ru values are based on nominal composition ratios with Rh and the Rh measured value. 
PHTD-C92-05.05A

IABLE 4.2. Expected Composition of 102-AZ Core 1 After Addition of $\mathrm{NaNO}_{2}, \mathrm{CsNO}_{3}$, and $\mathrm{NaNO}_{3}$

\begin{tabular}{|l|c|c|c|c|}
\cline { 2 - 6 } \multicolumn{1}{c|}{} & $\begin{array}{c}102-A Z \\
\text { Core \#1 (a) } \\
\text { moles E/L of feed }\end{array}$ & $\begin{array}{c}\text { NCAW SRAT Ref. Feed } \\
\text { FY91 Revision (a) } \\
\text { moles E/L of feed }\end{array}$ & $\begin{array}{c}\text { 102-AZ } \\
\text { Core \#1 (b) } \\
\text { g/100 g Oxide }\end{array}$ & $\begin{array}{c}\text { NCAW SRAT Ref. Feed } \\
\text { FY91 Revision (b) } \\
\text { g/100 g Oxide }\end{array}$ \\
\hline F & $4.46 E-03$ & $6.38 E-03$ & $6.53 E-02$ & $9.70 E-02$ \\
C & $6.34 E-04$ & $1.06 E-02$ & $1.68 E-02$ & $3.00 E-01$ \\
NO2 & $2.61 E-01$ & $4.35 E-01$ & $9.26 E+00$ & $1.60 E+01$ \\
NO3 & $1.16 E-01$ & $1.16 E-01$ & $5.56 E+00$ & $5.75 E+00$ \\
\hline PO4 (c) & $2.35 E-03$ & $1.03 E-03$ & $1.72 E-01$ & $1.03 E-03$ \\
SO3 & $7.59 E-03$ & $1.02 E-02$ & $4.68 E-01$ & $6.55 E-01$ \\
TIC (CO3) & $2.64 E-01$ & $1.25 E-01$ & $1.22 E+01$ & $6.00 E+00$ \\
TOC & $9.36 E-02$ & $1.39 E-02$ & & $1.34 E-01$ \\
\hline
\end{tabular}

(a) Assumes $125 \mathrm{~g}$ WO/L (IC \& Carbon concentrations were adjusted using wt\% oxide measurement).

(b) Calculations are based on normalizing nonvolitale oxides measured from ICP and IC to $100 \%$.

(c) The PO4 measurement in this table is soluble PO4 and is part of the total P shown in Table 3.1.

(d) Calculation is not performed since the composition of the organic carbon is not quantified.

The amount of formic acid required to achieve an acceptable redox potential is calculated from the concentration of nitrate and the weight of the sample. The recommended mole ratio of formic acid to nitrate is based on results of $K$. D. Wiemers simulant redox/rheology testing and is as follows (per conversation with K.D. Wiemers):

Moles formic acid $=2.5 *$ moles nitrate

The amount of acid to be added, based on this formula and the expected concentration of nitrate in the sample and recycle, is below that required to generate the second, larger hydrogen peak (Wiemers, Langowski and Powell 1991). Based on Wiemers' work for a batch size of $1.5 \mathrm{~L}$, the moles of formic acid needed to generate the larger hydrogen peak are as follows:

Moles formic acid $=0.62+2 *$ moles nitrite 
For the batch size of this test and the expected nitrite concentration in the waste, the required formic acid for this peak equates to 0.062 moles, which is $20 \%$ greater than the 0.052 moles of formic acid based on equation 2 . An assumption has been made that the constant term is proportional to scale, which is being confirmed by comparing the correlation to large scale IDMS results. Because a primary.purpose of this test is to observe hydrogen generation in fully radioactive samples, the formic acid will be added until the second hydrogen peak is observed. The anticipated formic acid to nitrate ratio will be 3.0, which is well within the range of formic acid/nitrate ratios $(2.5$ - 12.6) shown to achieve proper redox potentials in the resulting feed (Wiemers, Langowski and Powel1 1991).

\subsubsection{Test Operations and Data to be Obtained}

In preparation for the test, the radioactive formated slurry will be diluted to near the HWVP nominal feed concentration ( $31 \mathrm{~g}$ oxide/liter). The slurry will be heated to boiling to concentrate the slurry back to $125 \mathrm{~g}$ oxide/liter. Boil-off will be condensed, collected and analyzed for anions by IC, elements by ICP, and ammonia by selective ion electrode.

To initiate the test, cooling water will be run through the condensers, and the temperature of the waste slurry increased to $95 \pm 3^{\circ} \mathrm{C}$ and held for 10 minutes. The predetermined volume of formic acid will then added to the waste slurry at a rate of $0.027 \mathrm{ml} / \mathrm{min}(2.0 \mathrm{gal} / \mathrm{min} \mathrm{plant} \mathrm{scale} \mathrm{equivalent)} \mathrm{using} \mathrm{a}$ peristaltic pump. Based on the given flow rate and an 87 wt\% solution of formic acid, the addition period is expected to be about 104 minutes per batch.

A carrier/tracer gas of argon/helium will be introduced into the reaction vessel at a flow rate of approximately 0.12 standard liters per minute (SLPM). The off-gases generated by the formic acid addition will be swept out of the reaction chamber and through a condenser where a majority of the water vapor will condense and be caught in a trap for chemical characterization. The uncondensed gases will pass through a second condenser to bring the mixture to room temperature. 
The off-gases then pass in 1/8" I.D. stainless steel tubing (some sections of high density poly tubing will be used for flexibility) through a Drierite column and two HEPA filters and into a fume hood adjacent to the hot cell. The HEPA filters used during testing of the radioactive samples will be stored to allow analysis at a later date. The off-gases will be analyzed by the aforementioned analysis equipment located in the fume hood. The off-gas analyses include $\mathrm{H}_{2}, \mathrm{O}_{2}, \mathrm{~N}_{2}, \mathrm{CH}_{4}, \mathrm{CO}, \mathrm{CO}_{2}, \mathrm{~N}_{2} \mathrm{O}, \mathrm{NO} / \mathrm{NO}_{x}$, total hydrocarbons, ${ }^{129} \mathrm{I},{ }^{14} \mathrm{C}$ from $\mathrm{CO}_{2}$ and $\mathrm{NH}_{3}$. $\mathrm{NO}_{x}$ will be measured on a continuous basis with infrequent measurements of NO. Grab samples will be taken when hydrocarbons are present to characterize the volatile organic species. Further information about the types and frequency of analyses are provided in Table 4.3. Limited chemical characterization will be performed on the condensate as shown in Table 4.4.

Immediately following the formic acid addition, the temperature of the waste slurry is increased to boiling: $\left(101^{\circ} \mathrm{C}\right)$, and the sample is digested for 4 hours under boil off conditions. Because of the small sample sizes, and the potential to dry the samples out during boil off, water additions will be made to maintain a constant slurry volume (to the extent possible) during boil off. Throughout the formic acid addition and digestion, the $\mathrm{pH}$, temperature, and off-gas composition of the waste slurry will be monitored. Temperature and $\mathrm{pH}$ will be measured prior to heating the pre-formated slurry and after cooling down the formated slurry to obtain comparative data at ambient and elevated temperatures.

Following completion of digestion, a simulated recycle with composition shown in Table 4.5 will be added to the formated slurry. The recycle slurry at a concentration of $60 \mathrm{~g}$ recycle oxide/ $\mathrm{L}$ recycle will be added to the waste in a ratio of $0.12 \mathrm{~g}$ recycle oxide $/ 1.0 \mathrm{~g}$ waste oxide. The mixture will then be digested/boiled-off at boiling for approximately $2 \mathrm{hrs}$ with off-gas analysis. The formated mixture will be adjusted to $125 \mathrm{~g} \mathrm{TO} / \mathrm{L}$ to provide a consistent basis for comparison to physical properties in. the TDP. The formated waste slurry will be subsampled and characterized as indicated in Table 4.6. 
IABLE 4.3. Data Obtained During. Formating of the Waste (Off-Gas and 0ther)

\begin{tabular}{|c|c|c|c|c|}
\hline Analyte & Method & $\begin{array}{l}\text { Measurement } \\
\text { Interval }\end{array}$ & Intended Use & $\begin{array}{c}\text { Estimated } \\
\text { Data } \\
\text { Accuracy }\end{array}$ \\
\hline $\mathrm{H}_{2}$ & Gas Chromatograph/TCD & $0.25-1 \mathrm{~min}$. & Safety Issue - Compare simulant to radioactive & $\pm 5 \%$ \\
\hline $\mathrm{O}_{2}$ & Gas Chromatograph/TCD & 1-2 minutes & Understanding of reaction mechanisms & $\pm 5 \%$ \\
\hline $\mathrm{N}_{2}$ & Gas Chromatograph/TCD & $1-2$ minutes & Understanding of reaction mechanisms & $\pm .5 \%$ \\
\hline $\mathrm{He}$ & Gas Chromatograph/TCD & 1-2 mịnutes & Tracer gas required to calculate gas flow rate & $\pm 5 \%$ \\
\hline $\mathrm{CO}$ & Gas Chromatograph/TCD & 1-2 minutes & Understanding of reaction mechanisms & $\pm 5 \%$ \\
\hline $\mathrm{CO}_{2}$ & Gas Chromatograph/TCD & 1-2 minutes & Understanding of reaction mechanisms & $\pm 5 \%$ \\
\hline $\mathrm{N}_{2} \mathrm{O}$ & Gas Chromatograph/TCD & 1-2 minutes & $\begin{array}{l}\text { Safety Issue - increases flammability of } \\
\text { hydrogen }\end{array}$ & $\pm 5 \%$ \\
\hline $\mathrm{NO} / \mathrm{NO}_{x}$ & $\mathrm{NO} / \mathrm{NO}_{x}$ Analyzer & Continuous & Understanding of reaction mechanisms & $\pm 10 \%$ \\
\hline $\begin{array}{l}\text { Total } \\
\text { hydrocarbon }\end{array}$ & Flame Ionizatn Detectr & Cont inuous & To defend HWVPs design assumptions to State/EPA & TBD \\
\hline${ }^{129} I$ & Zeolite Scrubber/Count & Total (1) & To defend HWVPs design assumptions to State/EPA & TBD \\
\hline${ }^{129} \mathrm{I}$ & $\mathrm{NaOH}$ Scrubber/Counting & Total (1) & To defend HWVPs design assumptions to State/EPA & TBD \\
\hline${ }^{14} \mathrm{C}$ from $\mathrm{CO}_{2}$ & $\mathrm{NaOH}$ Scrubber/Counting & Total (1) & To defend HWVPs design assumptions to State/EPA & TBD \\
\hline NH3 (condensate) & Selective Ion Elect. & Total (1) & Safety Issue - Compare simulant to radioactive & TBD \\
\hline NH3 (in slurry) & Selective Ion Elect. & Init/End(2) & Safety Issue - Compare simulant to radioactive & TBD \\
\hline NH3 (in off-gas) & Drierite Column & Total (1) & Safety Issue - Compare simulant to radioactive & TBD \\
\hline $\mathrm{pH}$ & pH meter (temp. comp.) & 1 minute & Understanding of reaction mechanisms & $\pm 0.5 \mathrm{pH}$ \\
\hline Temperature & Thermocouple & I minute & To control temperature & $\pm 2.2^{\circ} \mathrm{C}$ \\
\hline
\end{tabular}


TABLE 4.4. Characterization of Off-Gas Condensate

\begin{tabular}{|c|c|c|c|c|}
\hline \multirow{2}{*}{$\begin{array}{c}\text { Type of } \\
\text { Analysis }\end{array}$} & \multicolumn{2}{|c|}{ Number of Analysis } & \multirow{2}{*}{$\begin{array}{l}\text { Estimated } \\
\text { Data } \\
\text { Accuracy }\end{array}$} & \multirow[b]{2}{*}{ Intended Use } \\
\hline & Radioactive & Simulant & & \\
\hline ICP & 2 & 2 & $\pm 15 \%$ & General Process Information \\
\hline IC & 2 & 2 & $\pm 15 \%$ & General Process Information \\
\hline Carbon & 2 & 2 & TBD & General Process Information \\
\hline $\mathrm{pH}$ & 2 & 2 & $\pm .5 \mathrm{pH}$ & General Process Information \\
\hline $\mathrm{NH}_{3}$ & 2 & 2. & TBD & Material Balance \\
\hline${ }^{14} \mathrm{C}$ & 2 & & TBD & Material Balance \\
\hline $129 \mathrm{I}$ & 2 & & TBD & Material Balance \\
\hline
\end{tabular}

IABLE 4.5. Composition of Recycle

\begin{tabular}{|c|c|c|c|}
\hline Sources & $\begin{array}{c}\text { g Recycle Source/ } \\
L \text { of Recycle }\end{array}$ & Oxide & $\begin{array}{l}\text { g Recycle Oxide/ } \\
L \text { of Recycle }\end{array}$ \\
\hline $\mathrm{CdO}$ & 2.00 & CdO & 2.01 \\
\hline $\mathrm{KMnO}_{4}$ & 1.09 & $\mathrm{MnO}_{2}$ & 0.60 \\
\hline $\mathrm{NaOH}$ & 24.34 & $\mathrm{Na}_{2} \mathrm{O}$ & 25.17 \\
\hline $\mathrm{Na}_{3} \mathrm{PO}_{4}$ & 4.62 & $P_{2} O_{5}$ & 2.01 \\
\hline $\mathrm{HNO}_{3}$ & 40.65 & $\mathrm{NO}_{3}^{-}$ & 40.27 \\
\hline $\mathrm{NaCl}$ & 0.07 & $\mathrm{CI}^{-}$ & 0.04 \\
\hline $\mathrm{Na}_{2} \mathrm{C}_{2} \mathrm{O}_{4}$ & 7.54 & TOC & 1.36 \\
\hline $\begin{array}{c}\text { Diatomaceous } \\
\text { Earth }\end{array}$ & 20.00 & $\begin{array}{c}\text { Diatomaceous } \\
\text { Earth }\end{array}$ & 20.13 \\
\hline Zeolite (IE-96) & 10.00 & Zeolite (IE-96) & 10.07 \\
\hline SUM & 110.30 & SUM & $60.00(a)$ \\
\hline \multicolumn{4}{|c|}{$\begin{array}{l}\text { NOTE: Formic acid is added to the recycle just prior to adding it to the } \\
\text { waste in the amount of } 0.19 \mathrm{moles} \mathrm{HCOOH} / \mathrm{L} \text { recycle. } \\
\text { (a) } \mathrm{NO}_{3}, \mathrm{Cl}^{-} \text {, and TOC are not included in oxide sum. }\end{array}$} \\
\hline
\end{tabular}


TABLE 4.6. Physical, Chemical, Radiochemical, and Rheological Characterization of Formated Slurry

\begin{tabular}{|c|c|c|c|c|}
\hline \multirow[b]{2}{*}{ Type of Analyses } & \multicolumn{2}{|c|}{ Number of Analysis } & \multirow{2}{*}{$\begin{array}{c}\text { Estimated (a) } \\
\text { Data } \\
\text { Accuracy } \\
\end{array}$} & \multirow[b]{2}{*}{ Intended Use } \\
\hline & Radioactive & Simulant & & \\
\hline \multicolumn{5}{|l|}{ Physical Charecterization } \\
\hline Density & 2 & 2 & $\pm 2 x$ & Comparison with TDP \& simulant data \\
\hline Settling Rate & 2 & 2 & TBD. & Comparison with TOP \& simulant date \\
\hline Volx Settled Sol ids & 2 & 2 & $\pm 10 x$ & Comparison with TDP \& simulant date \\
\hline $\begin{array}{l}\text { Density of Centrifuged Solids } \\
\text { and Supernate }\end{array}$ & 2 & 2 & $\begin{aligned} \pm 5 x \\
\pm 1 x \\
\end{aligned}$ & $\begin{array}{l}\text { Help understanding of long-term settling } \\
\text { behavior }\end{array}$ \\
\hline Volx and wtX Centrifuged Solids & 2 & 2 & $\pm 10 x, 5 x$ & $\begin{array}{l}\text { Melp understanding of long-term settling } \\
\text { behavior }\end{array}$ \\
\hline HtX Dissolved Sol ids & 2 & 2 & $\pm 10 x$ & Understanding of total sol ids measurement \\
\hline WtX Total Solids & 2 & 2 & $\pm 5 x$ & Comparison with TOP \& simulant data \\
\hline wtX Total Oxides & 2 & 2 & $\pm 5 x$ & Comparison with TOP \& simulant data \\
\hline Particle Size Distribution $(5.220 \mu \mathrm{m})$ & 1 & 1 & $\pm 10 \%$ & Interpretation of settl ing rate dato \\
\hline Shear Stress vs. Shear Rate (apparent viscosity) & $\mathbf{2}$ & 2 & TBD & Comparison with TDP \& simulant date \\
\hline \multicolumn{5}{|l|}{ Chemical Characterization } \\
\hline PH & 1 & 1 & $\pm 0.5 \mathrm{pH}$ & Comparison with TDP \& simulant data \\
\hline $\begin{array}{l}\text { Elemental Analysis by ICP(b) (supernate } \\
\text { slurry) }\end{array}$ & 3 & 3 & $\pm 5-20 x^{(c)}$ & Determine composition (waste + recycle) \\
\hline Anions by $1 c^{(d)}$ & 1 & 1 & $\pm 15 x^{(e)}$ & Understanding of formating reactions \\
\hline Total Carbon (TC) & 1 & 1 & TBD & Needed to calculate TIC \\
\hline Total Organic Carbon (TOC) & 1 & 1 & IBD & Understanding of formating reactions \\
\hline $\begin{array}{l}\text { Total Inorganic Carbon (TIC) by Subtraction (TC- } \\
\text { TOC) }\end{array}$ & 1 & 1 & TBD & Understanding of formating reactions \\
\hline \multicolumn{5}{|l|}{ Radiochenical Characterization } \\
\hline c-14 & 1 & 0 & TBD & Complete mass balance on formating \\
\hline $1-129$ & 1 & 0 & TBD & Complete mass balance on formating \\
\hline Pu-239 (slurry and Supernate) & 2 & 0 & TBD & Support criticality assumptions \\
\hline
\end{tabular}

(a) Data accuracies are estimated to be 2 times observed data precision of prior samples.

(b) Inductively coupled plasma atomic emission spectroscopy measures Ag, Al, As, B, Ba, Be, Ca, Cd, Ce, Co, Cr, Cu, Dy, Fe, K, La, Li, Mg, Mn, Mo, $\mathrm{Na}, \mathrm{Nd}, \mathrm{Mi}, \mathrm{P}, \mathrm{Pb}, \mathrm{Re}, \mathrm{Rh}, \mathrm{Ru}, \mathrm{Sb}, \mathrm{Se}, \mathrm{Sr}, \mathrm{Sr}, \mathrm{Te}, \mathrm{Th}, \mathrm{Ti}, \mathrm{Tl}, \mathrm{U}, \mathrm{V}, \mathrm{Zn}$, and $2 r$. Two preparation techniques are needed on sol ids to obtain $K$, Na, Mi, and $2 r$.

(c) Data accuracies for ICP are dependent upon concentration level, analyte, interference corrections, and basic matrix. Most analytes are expected to be between \pm 5 and $\pm 20 \%$ accurate.

(d) Ion chromatography measures soluble $\mathrm{F}^{-}, \mathrm{Cl}^{-}, \mathrm{PO}_{3}^{-3}, \mathrm{SO}_{4}^{-2}, \mathrm{NO}_{3}^{-}, \mathrm{MO}_{2}^{-}$, and $\mathrm{HCO}_{2}^{-}$(if possible).

(e) After leaching accuracy. 
PHTD-C92-05.05A

\subsection{FRIT ADDITION}

Prior to the formating step, frit will be formulated and prepared specifically for the core sample. Formulation of the frit will be such that when mixed with the core sample it will produce a glass of acceptable glass properties (durability, electrical conductivity, viscosity, and phase separation) as determined by the Composition Variability Study (CVS) models, and will produce a glass composition that optimizes validation of the CVS envelope (each core sample glass is designed with a different composition to fully test the CVS envelope). The waste composition to be used in formulating the frit and resulting glass composition is the chemical analyses of the 102AZ Core 1 washed solids shown in Tables 4.1 and 4.2 properly ratioed with the recycle composition shown in Table 4.5. Frit of the appropriate size ($80 /+200$ mesh with maximum of $10 \%$ fines) will be prepared prior to formating of the waste siurry to prevent unnecessary delays in processing the waste through to a dried melter feed. The effects of leaving the formated waste in a wet form for extended periods of time have not been fully investigated.

The formated slurry will be adjusted to a concentration of $140 \pm 5 \mathrm{~g} / \mathrm{L}$ of waste oxides or $157 \mathrm{~g}$ waste + recycle oxides prior to frit addition. Frit will then be added in a ratio of $343 \mathrm{~g}$ frit / (140 g waste oxides $+17 \mathrm{~g}$ recycle oxides). This will result in a 28 wt\% waste loading in the glass. The resulting melter feed will be heated and maintained at boiling conditions for at least $1 \mathrm{hr}$. Boil-off during this period will be condensed, collected, and analyzed for anions by IC, elements by ICP, and ammonia by selective ion electrode. The slurry will be adjusted to $500 \mathrm{~g} / \mathrm{L}$ of oxides and will be characterized as indicated in Table 4.7. The characterized melter feed will then be dried at $90^{\circ} \mathrm{C}$ and transported to the 324 Building, D-cell for calcining and vitrification.

\subsection{CALCINING AND VITRIFICATION}

The objective of the calcination and vitrification of the melter feed is to transform the feed into a homogeneous glass under conditions similar to those experienced in a ceramic melter. The dried melter feed will be calcined to transform the feed chemicals into oxides similar to the chemical 
IABLE 4.7. Physical, Chemical and Rheological Characterization of Melter Feed

\begin{tabular}{|c|c|c|c|c|}
\hline \multirow[b]{2}{*}{ Type of Analyses } & \multicolumn{2}{|c|}{ Number of Analysis } & \multirow{2}{*}{$\begin{array}{c}\text { Estimated }^{(a)} \\
\text { Data } \\
\text { Accuracy } \\
\end{array}$} & \multirow[b]{2}{*}{ Intended Use } \\
\hline & Radioactive & simulant & & \\
\hline \multicolumn{5}{|l|}{ Physical Characterization } \\
\hline Density & 2 & 2 & $\pm 2 x$ & Comparison with TOP \& simulant data \\
\hline Settling Rate & 2 & 2 & TBO & Comparison with TDP simulant data \\
\hline Volx settled Sol ids & 2 & 2 & $\pm 10 \%$ & Comparison with IDP \& simulant data \\
\hline $\begin{array}{l}\text { Density of Centrifuged Solids } \\
\text { and Supernate }\end{array}$ & 2 & 2 & $\begin{array}{l} \pm 5 x \\
\pm 1 x \\
\end{array}$ & $\begin{array}{l}\text { Understanding of long-term settling } \\
\text { behavior }\end{array}$ \\
\hline VolX and WtX Centrifuged Sol ids & 2 & 2 & $\pm 10 x, 5 x$ & $\begin{array}{l}\text { Understanding of long-term settling } \\
\text { behavior }\end{array}$ \\
\hline WtX Dissolved Sol ids & 2 & 2 & $\pm 10 x$ & Understanding of total solids measurement \\
\hline WtX Total Solids & 2 & 2 & $\pm 5 \%$ & Comparison with TDP \& 8 imulant data \\
\hline WtX Total Oxides & 2 & 2 & $\pm 5 x$ & Comparison with TDP 2 simulant date \\
\hline Particle size Distribution $(5-220 \mu \mathrm{m})$ & 1 & 1 & $\pm 10 \%$ & Interpretation of settling rate data \\
\hline Shear stress vs. Shear Rate (apparent viscosity) & 2 & 2 & TBD & Comparison with TDP 2 simulant data \\
\hline \multicolumn{5}{|l|}{ Chemical Characterization } \\
\hline PH & 1 & 1 & $\pm 0.5 \mathrm{pH}$ & Comparison with TOP 2 simulant data \\
\hline Elemental by $\operatorname{ICP}^{(\mathrm{b})}$ (supernate \& slurry) & 3 & 3 & $\pm 5-20 x^{(c)}$ & Determine composition (waste \& frit) \\
\hline Anions by $1 \mathrm{C}^{(\mathrm{d})}$ & 1 & 1 & $\pm 15 x^{(e)}$ & $\begin{array}{l}\text { Comparison of measurement in formated } \\
\text { slurry }\end{array}$ \\
\hline Total Carbon (TC) & 1 & 1 & TBD & $\begin{array}{l}\text { Comparison of measurement in formated } \\
\text { slurry }\end{array}$ \\
\hline Total Organic Carbon (TOC) & 1 & 1 & TBD & $\begin{array}{l}\text { Comparison of measurement in formated } \\
\text { slurry }\end{array}$ \\
\hline $\begin{array}{l}\text { Potal inorganic Carbon (TIC) by Subtraction (TC- } \\
\text { TOC) }\end{array}$ & 1 & 1 & TBD & $\begin{array}{l}\text { Comparison of measurement in formated } \\
\text { slurry }\end{array}$ \\
\hline
\end{tabular}

(a) See Table 4.4.

(b) Inductively coupled plasma atomic enission spectroscopy measures Ag, Al, As, B, Ba, Be, Ca, Cd, Ce, Co, Cr, Cu, Oy, Fe, K, La, Li, Mg, Mn, Mo, $\mathrm{Ma}, \mathrm{Md}, \mathrm{Mi}, \mathrm{P}, \mathrm{Pb}, \mathrm{Re}, \mathrm{Rh}, \mathrm{Ru}, \mathrm{Sb}, \mathrm{Se}, \mathrm{Sr}, \mathrm{Sr}, \mathrm{Te}, \mathrm{Th}, \mathrm{Ti}, \mathrm{Tl}, \mathrm{U}, \mathrm{V}, \mathrm{Zn}$, and Zr. Elements too low for detection in the melter feed of the first to core samples include As, Ce, Co, Dy, Mo, Re, Rh, Ru, Sb, Se, Te, Th, Tl, and $V$ in the sturry and Th in the supernate, Two preparation techniques are needed on solids to obtain $\mathrm{K}, \mathrm{Na}, \mathrm{Mi}$, and $\mathrm{Zr}$.

(c) See Table 4.4.

(d) Ion chromatography measures soluble $\mathrm{F}^{-}, \mathrm{Cl}^{-}, \mathrm{PO}_{3}^{-3}, \mathrm{SO}_{4}^{-2}, \mathrm{NO}_{3}^{-}$, and $\mathrm{MO}_{2}^{-}$.

(e) See Table 4.4. 
decompositions that occur in the ceramic melter cold cap. The calcine will then be vitrified to fuse the frit and waste into a homogeneous glass. The dried melter feed will be transferred to a Denver Fire Clay (DFC) crucible and calcined for two hours at $600^{\circ} \mathrm{C}$ in a Lindberg muffle furnace. After cooling, the calcined feed will be weighed to determine the calcination weight loss. The feed will then be melted in a DFC crucible at $1150^{\circ} \mathrm{C}$ for two hours in a Lindberg muffle furnace. The two hour soak is to ensure glass homogeneity and is based on past experience of crucible melts. The molten glass will be poured into a bar mold that has been preheated to about $300^{\circ} \mathrm{C}$.- The glass bar will then be annealed in a separate muffle furnace at $500^{\circ} \mathrm{C}$ for two hours and allowed to slowly cool to room temperature. Depending on the amount of available feed, the vitrification may be performed in batches resulting in more than one glass bar.

\subsection{PRODUCT TESTING}

One of the major objectives of product testing is to provide preliminary confirmation that the nonradioactive waste feed simulant recipe is adequate for addressing the testing needs of design, safety, WFQ, permitting, etc. The radioactive glasses will be tested for density, chemical and radiochemical composition, redox ( $\mathrm{Fe}^{+2} /$ total $\mathrm{Fe}$ ), crystallinity, and durability. The nonradioactive glasses will be tested for density, chemical composition, redox $\left(\mathrm{Fe}^{+2} /\right.$ total $\left.\mathrm{Fe}\right)$, viscosity, electrical conductivity, crystallinity by optical microscope and durability. The glass durabilities will be determined using the Product Consistency Test (PCT) with crushed glass.

In preparation for a PCT leach test, a section of glass will be crushed to $\leq 100$ mesh. The crushed glass particles will be sifted to obtain samples of $-100 /+200$ mesh for use in the PCT test. Portions of the -200 mesh glass will be submitted for chemical and radiochemical analyses as shown in Table 4.8. The remaining glass will be archived.

A PCT leach test will be performed in the hot cell on the radioactive and simulant glasses under identical conditions to allow a direct comparison. The in-cell test will be performed in 324 Building, D-cell. A PCT leach test 
IABLE 4.8. Physical, Chemical and Radiochemical Characterization of Glass

\begin{tabular}{|c|c|c|c|c|}
\hline \multirow[b]{2}{*}{ Type of Analyses } & \multicolumn{2}{|c|}{ Number of Analysis } & \multirow{2}{*}{$\begin{array}{c}\text { Estimated } \\
\text { Data } \\
\text { Accuracy } \\
\end{array}$} & \multirow[b]{2}{*}{ Intended Use } \\
\hline & Radioactive & simulant & & \\
\hline \multicolumn{5}{|l|}{ Physical and Chemical characterization } \\
\hline Density & 1 & 1 & TBD & Comparison with simulant data \\
\hline Elemental by $I C p(a)$ & 4.(c) & 2 & $\pm 20 x$ & MAPS 1.1 , release rate calc. \\
\hline Crystall inity by $X$-ray Diffraction & 1 & & IBD & General glass information \\
\hline $\mathrm{Fe}^{+2} / \mathrm{Fe}$ Total & 1 & 1 & IBD & Process date \\
\hline Viscosity at $1150^{\circ} \mathrm{C}$ & & 1 & TBD & CVS Comparison-Processability \\
\hline Electrical Conductivity & & 1 & TBD & Cvs Comparison-Processability \\
\hline \multicolumn{5}{|l|}{ Radiochemical Characterization } \\
\hline GEA $(b)$ & 1 & & $\pm 5 x$ & MAPS 1.2.1 - release rate data \\
\hline Total Alpha & 1 & & TBD & General glass information \\
\hline Total Beta & 1 & & TBD & General glass information \\
\hline Total Gamma (from GEA) & 1 & & $+5 x$ & General Glass information \\
\hline sr-90 & 1 & & TBD & Release rate data \\
\hline Tc- 99 & 1 & & TBD & Release rate dato \\
\hline $1-129$ & 1 & & TBD & Release rate data \\
\hline$A m-241$ & 1 & & TBD & Release rate data \\
\hline Cm-242, 243+244 (from MM-241 separation) & 1 & & rBD & Release rate data \\
\hline Pu-238, 239+240 & 1 & & TBD & Release rate data \\
\hline Total U & 1 & & $T B D$ & Release rate data \\
\hline
\end{tabular}

(a) Inductively coupled plasma atomic emission spectroscopy measures Ag, Al, As, B, Ba, Be, Ca, Cd, Ce, Co, Cr, Cu, OY, Fe, K, La, Li, Mg, Mn, Mo, Na, Md, Mi, P, Pb, Re, Rh, Ru, Sb, Se, Sr, Sr, Te, Th, Ti, II, U, V, Zn, and Zr. Elements too low for detection in the first two core glasses include $\mathrm{Ce}, \mathrm{Co}, \mathrm{Dy}, \mathrm{P}, \mathrm{Re}, \mathrm{Rh}, \mathrm{Ru}, \mathrm{Sb}, \mathrm{Se}, \mathrm{Th}, \mathrm{Tl}$, and $\mathrm{V}$. Two preparation techniques are needed on solids to obtain $\mathrm{K}, \mathrm{Ma}, \mathrm{Mi}$, and $\mathrm{Zr}$.

(b) Gamma energy analysis. Radionicl ides measurable on the first two core sample glasses include ${ }^{60} \mathrm{Co},{ }^{106} \mathrm{Ru},{ }^{125} \mathrm{sb}_{1}{ }^{134} \mathrm{Cs}_{\mathrm{C}_{5}}{ }^{137} \mathrm{Cs},{ }^{144} \mathrm{Ce}{ }^{154} \mathrm{Eu}$,

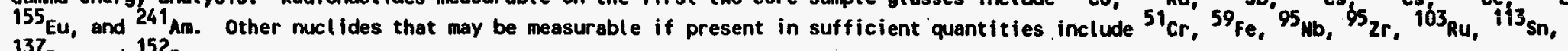
$137 \mathrm{Ba}$, and ${ }^{152} \mathrm{Eu}$.

(c) Provided samples are available, a CVS referrence glass or MCC round robin glass will be analyzed as well. If practical, replicate samples will be run at different times to avoid underestimating uncertainty. 
will also be performed out-of-cell on the simulant glass to provide a direct comparison with CVS model predictions. The out-of-cell PCT leach tests will be performed in teflon leach containers and in the same containers used in the hot cell. Teflon is unacceptable in the hot cell, due to radiolytic degradation of Teflon. The selection of leach container for the in-cell PCT leach test will be made based on final results of 101-AZ leach testing.

Lessons learned from in-cell leach testing on core samples from DST 101AZ will be incorporated into this and future testing. The lessons learned are that 1) MCC-1 leach tests are highly sensitive to temperature and 2) fusedsilica lined leach containers yield reduced release rates in MCC-1 tests when compared to Teflon (Elliott, Morrey and Tingey 1991). The affect of temperature variation and differences in leach containers are more pronounced in the MCC-1 test than in the PCT, due to the smaller sample surface area in MCC-1. Nonetheless, temperature control and selection of leach container shall be considered critical in both tests.

Improvements to the in-cell setup include a new leach oven with reduced temperature gradient and temperature measurement and control by thermistor ( \pm $0.1^{\circ} \mathrm{C}$ ) instead of thermocouples $\left( \pm 2.2^{\circ} \mathrm{C}\right)$. Work is ongoing in FY 1991 carryover work to allow selection of the most appropriate leach container. The potential leach containers for in-cell testing include stainless steel, titanium and gold plated stainless steel. Stainless steel containers (type of container used by DWPF and specified by PCT) create a reducing atmosphere and remove actinides from the leachate by actinide plating on the walls. The actinides can be recovered by acid stripping, but the results will not represent the actinide concentration remaining in solution under repository conditions. Fused-silica lined containers have been shown to leach silica, which appears to affect release rates. The release of silica is not consistent between liners, which increases inter-sample variability. Titanium containers seem to be a viable option and are being tested in the hot cell presently. Gold plated containers have been used by others with some successes and some failures. The liners work well if the plating is flawless, but a pinhole in the plating will ruin a test. Advantages and drawbacks of each container will be evaluated prior to selection. 
In preparation for sample preparation for leach testing, the glass bar will be trimmed using a low speed wafering saw with a diamond blade. The sides of the glass bar will be trimmed prior to cutting the samples so that none of the sides of the monoliths originate from the glass-to-metal interfaces of the bar mold.

At a minimum, the following number of samples will be included and analyzed in each in-cell leach test: 2 radioactive samples, 2 simulant samples, and one blank. As oven space and sample availability permit, additional radioactive, simulant, blank and reference samples may be added. The reference sample may include a CVS standard glass or a MCC round robin glass. At a minimum, the following number of samples will be included and analyzed in each out-of-cell leach test: 2 simulant samples, and one blank. The leachates will be analyzed as shown in Table 4.9.

A very preliminary evaluation of CVS data and correlations was performed to determine how imprecision in glass composition translates into uncertainty in glass properties (e.g., durability). A $\pm 5 \%$ analysis can translate into a $40 \%$ RSD on durability. Therefore, an accuracy of $\pm 5 \%$ on analysis of the glass composition is desirable. This may be difficult given the estimated accuracy of ICP ( $\pm 5-20 \%$ not including preparation). At this point, funding and analytical capability on radioactive samples limits the options for analysis. Excess glass will be archived in the event further analysis is desired. 
IABLE 4.9. Chemical and Radiochemical Analysis of Leachates

w

\begin{tabular}{|c|c|c|c|c|}
\hline \multirow[b]{2}{*}{ Type of Analyses. } & \multicolumn{2}{|c|}{ Number of Analysis. } & \multirow{2}{*}{$\begin{array}{l}\text { Estimated } \\
\text { Data } \\
\text { Accuracy }\end{array}$} & \multirow[b]{2}{*}{ Intended Use } \\
\hline & Radioactive & Simulant & & \\
\hline \multicolumn{5}{|l|}{ Physical and Chemical Characterization } \\
\hline Elemental by ICP( 8$)$ & 2 & 2 & $\pm 15 x$ & WFa - release rote data \\
\hline Anions by $1 c^{(b)}$ & 2 & 2 & $\pm 15 \%$ & General leachate information \\
\hline pH & 2 & 2 & $\pm 0.5 \mathrm{pH}$ & General leachate information \\
\hline \multicolumn{5}{|l|}{ Radiochenical Characterization } \\
\hline GEA(b) & 1 & & $\pm 5 x$ & Release rate data \\
\hline Total Alpha & 1 & & $\pm 7 x$ & General leachate information \\
\hline Total Beta & 1 & & $\pm 3 \mathbf{x}$ & General leachate information \\
\hline Total Gamna (from GEA) & 1 & & $\pm 5 x$ & General leachate information \\
\hline $5 r-90$ & 1 & & $\pm 7 x$ & Release rate data \\
\hline Tc-99 & 1 & & TBD & Release rate data \\
\hline$A m-241$ & 1 & & $\pm 16 \%$ & Release rate data \\
\hline $\mathrm{Cm}-243,244$ (from AM-241 separation) & 1 & & $\pm 60 \%$ & Release rate data \\
\hline Pu-238, 239+240 & 1 & & $\pm 9 x$ & Release rate data \\
\hline Total U & 1 & & $\pm 10 x$ & Release rate data \\
\hline
\end{tabular}

(a) Inductively coupled plasma atomic emission spectroscopy measures Ag, Al, As, B, Ba, Be, Ca, Cd, Ce, Co, Cr, Cu, Dy, Fe, K, La, LI, Mg, Mn, Mo, $\mathrm{Ma}, \mathrm{Nd}, \mathrm{Mi}, \mathrm{P}, \mathrm{Pb}, \mathrm{Re}, \mathrm{Rh}, \mathrm{Ru}, \mathrm{Sb}, \mathrm{Se}, \mathrm{Sr}, \mathrm{Sr}, \mathrm{Te}, \mathrm{Th}, \mathrm{Ti}, \mathrm{Tl}, \mathrm{U}, \mathrm{V}, \mathrm{Zn}$, and $\mathrm{Zr}$. Elements too low for detection in MCC-1 leachates from the first two core glasses include Be, Ce, Co, Dy, La, Nd, Re, Rh, Sb, Te, Th, Il, and V.

(b) Garma energy analysis. Radionuclides measurable in MCC-1 from the first two core sample glassies include ${ }^{60} \mathrm{Cog}^{125}{ }_{\text {Sb }}{ }^{134} \mathrm{Cs}_{13}{ }^{137} \mathrm{Cs}_{\text {. }}{ }^{\text {Muclides }}$

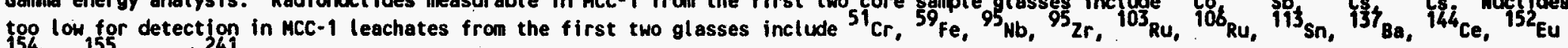
$154 \mathrm{Eu}$, ${ }^{155} \mathrm{Eu}$, and $24 \mathrm{Am}$. 


\subsection{TREATMENT OF DATA}

\subsection{DATA REDUCTION METHODS}

\subsubsection{Off-Gas Calculations}

Data from the GC/TCDs, THC and NO/NOx analyzers are generated in mole percents or ppm in the sample gas. For all species measured prior to the NO/NOX analyzer $\left(\mathrm{H}_{2}, \mathrm{O}_{2}, \mathrm{~N}_{2}, \mathrm{CH}_{4}, \mathrm{CO}, \mathrm{CO}_{2}, \mathrm{~N}_{2} \mathrm{O}\right.$ and TOCs $)$, the gas generation rates (moles/min) can be calculated directly from the measured gas species concentrations and the instantaneous total molar flow rate. The instantaneous total molar flow rate is calculated directly from the measured helium concentration. For $\mathrm{NO}_{\mathrm{NO}}$, and $\mathrm{THC}$ a dilution factor must be calculated for the compressed air/sample gas mixture. The mass flow controllers on both the compressed air and sample gas are calibrated to a specific flowrate using a given composition of gas. The sample gas, of course, changes in composition during the test; and a correction factor will have to be calculated for the mass flow controller as a function of time. This will allow calculation of $\mathrm{NO} / \mathrm{NO}_{x}$ concentrations and total hydrocarbon concentrations in the off-gas and calculation of the gas fraction sent to the NO/NOX analyzer needed for calculation of total ${ }^{14} \mathrm{C}$ and ${ }^{129} \mathrm{I}$ releases.

\subsubsection{Rheological Calculations}

The rheological data for the formated slurry and melter feed are generated in the form of a rheogram or flow curve, which is a plot of shear stress as a function of shear rate. The HWVP feed simulants as well as the radioactive wastes exhibit non-Newtonian fluid behavior, in which shear stress is a non-linear function of the shear rate. The data representing the shear stress versus shear rate will be fit to a yield-pseudoplastic rheological model to describe the behavior of these fluids. The relationship between the shear stress and the shear rate for this model is:

$$
T=T_{y}+K(c)^{n}
$$

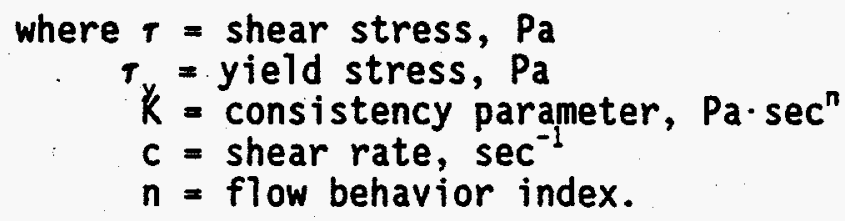




\subsubsection{Normalized Release}

Normalized releases are calculated for cations and radionuclides in the glass from PCT results. The normalized releases allow comparison of glasses with differing compositions. Releases will be calculated for cation and radionuclide species using the formula

$$
N L_{i j}=\left(C_{i j}-B_{i}\right) /\left[f_{i}\left(S_{j} / V_{j}\right)\right]
$$

where $\mathrm{NL}_{i j}=$ normal ized release of element $i$ from specimen $j$

$C_{i j}=$ concentration of element $i$ in leachate from specimen $j$

$B_{i}{ }_{i j}=$ concentration of element $i$ in leachate from blank

$f_{i}=$ average mass fraction of element $i$ in the specimen

$s_{j}^{i}=$ surface area of specimen $j$

$v_{j}=$ initial volume of leachant in vessel containing specimen $j$

\subsubsection{Statistical Treatment of Data}

Because of limited sample sizes and budget, duplicate or triplicate analyses are not performed, except in a few cases. Where duplicate or triplicate analyses are available (ICP on formated slurry, melter feed, glass and leachates), standard deviations and percent relative standard deviations will be calculated.

\section{$5: 2$ EXPECTED FINAL DATA FORM}

Data obtained from this study will be combined with data from testing of the first two NCAW core samples and reported in one final report. Data from testing the core samples will be compared to prior HWVP simulant data, SRL. and West Valley data, and model predictions, where appropriate. Figure 5.1 shows the proposed final report outline for the results and analyses sections, and indicates comparisons that will be made. Off-gas analysis data will be reported in a letter report.

\subsubsection{Off-Gas Analysis}

Graphs will be generated for each test to show interrelationships of gas components. Gas generation rates of each off-gas component will be plotted as a function of time on a separate graph for each test. Gas stream components 


\begin{tabular}{|c|c|c|}
\hline \multirow[t]{7}{*}{7.0} & \multicolumn{2}{|c|}{ Results } \\
\hline & 7.1 & $\begin{array}{l}\text { Washed solids } \\
\text { - Rheological (Core 1, Core 2, Core 3, simulants, TDP) } \\
\text { Physical (Core 1, Core 2, Core 3, simulants, TDP) } \\
\text { - Chemical (Core 1, Core 2, Core 3, simulants, TDP) } \\
\text { - Radiochemical (Core 1, Core 2, Core 3, TDP) }\end{array}$ \\
\hline & 7.2 & $\begin{array}{l}\text { Formated slurry } \\
\text { Rheological (Core 1, Core 2, Core 3, simulants, TDP) } \\
\text { - Physical (Core 1, Core 2, Core 3, simulants, TDP) } \\
\text { - Chemical (Core 1, Core 2, Core 3, simulants) }\end{array}$ \\
\hline & 7.3 & $\begin{array}{l}\text { Melter Feed } \\
\text { - Rheological (Core 1, Core 2, Core 3, simulants, TDP) } \\
\text { Physical (Core 1, Core 2, Core } 3 \text {, simulants, TDP) } \\
\text { - Chemical (Core 1, Core 2, Core 3, simulants) } \\
\text { - Radiochemical (Core 1, Core 2) }\end{array}$ \\
\hline & 7.4 & $\begin{array}{l}\text { Glass } \\
\text { Physical (Core 1, Core 2, Core 3, simulants) } \\
\text { - Radiochemical (Core 1, Core 2, Core } 3 \text { ) } \\
\text { - Durability (Core 1, Core 2, Core } 3 \text {, simulants, CVS) } \\
\text { - Crystallinity (Core 1, Core 2, Core } 3 \text {, simulants) } \\
\text { - Viscosity, Electrical Conductivity (simulants, CVS) }\end{array}$ \\
\hline & 7.5 & $\begin{array}{l}\text { Elemental mass balance } \\
\text { - Core } 1 \\
\text { - Core } 2 \\
\text { - Core } 3 \\
\text { Simulants }\end{array}$ \\
\hline & 7.6 & Observed analytical precision \\
\hline \multirow[t]{5}{*}{8.0} & \multicolumn{2}{|c|}{ Analyses } \\
\hline & 8.1 & $\begin{array}{l}\text { Comparison with HWVP Flowsheet, where possible (i.e., washing } \\
\text { efficiencies, etc.) }\end{array}$ \\
\hline & 8.2 & $\begin{array}{l}\text { Comparison with CVS model predictions (Core 1, Core 2, Core 3, } \\
\text { Simulants, DWPF?, West Valley?) }\end{array}$ \\
\hline & 8.3 & $\begin{array}{l}\text { Comparison with DWPF, West Valley, other ATM-10 radioactive } \\
\text { results, where possible }\end{array}$ \\
\hline & 8.4 & $\begin{array}{l}\text { Comparison with HWVP simulant database and correlations } \\
\text { (Larson's Handbook), where possible } \\
\text { Physical properties } \\
\text { - Rheological properties }\end{array}$ \\
\hline
\end{tabular}

FIGURE 5.1. Final Report Outline for Results and Analyses Sections 
not generated by the reaction (i.e., $\mathrm{Ar}$, He, and $\mathrm{O}_{2}$ ) will be omitted from the plots; and in addition, gases with little or no generation rate may be omitted for clarity. Other test parameters and conditions such as temperature, $\mathrm{pH}$, and formic acid added will be plotted as a function of time for direct comparison with the gas generation data.

Graphs will be generated to provide a comparison between radioactive and simulant data and to show repeatability (based on two runs) of the radioactive and simulant testing. A separate plot showing results for $\mathrm{H}_{2}$ from each test run will be provided with gas generation rates versus time. Since the test runs of this study are duplicates, the anticipated outcome is that results from the radioactive runs will be the same within experimental error; and the simulant and radioactive results may be similar or different, depending on the significance of the waste differences.

As appropriate, data will be scaled-up and plotted against correlations generated by Wiemers (Wiemers, Langowski and Powell 1991).

The total organic carbon, ${ }^{129} \mathrm{I},{ }^{14} \mathrm{C}$, and $\mathrm{NH}_{3}$ in the off-gas will be reported as total quantities released. Mass balances for the formating operation will be performed on ${ }^{129} \mathrm{I},{ }^{14} \mathrm{C}$ and $\mathrm{NH}_{3}$. The ability to close the respective material balances will depend on the accuracy of the measurement in the slurries.

\subsubsection{Formic Acid Addition and Melter Feed Preparation}

The chemical, physical and radiochemical data from the formated slurry and melter feed will be reported in table format. The data will be setup in such a way as to make simple comparisons between simulant, radioactive and TDP values. Settling rate data from the formated slurry and melter feed will also be reported in graph format to show settling behavior as a function of time. As appropriate, physical data (e.g., density, viscosity, etc) will be plotted on existing graphs in the Technical Manual (Larson 1989).

Chemical data for the washed solids, formated slurry, melter feed and glass will be converted from concentration units to wt \% oxides. Both measured (weight of a fired sample) and calculated (calculated ICP elemental concentrations measured by ICP) total oxides will be provided for comparison. 
The wt \% oxide units are convenient for comparisons between different samples and the TDP, but the calculation introduces additional error. Concentration values will be reported in addition to wt \% oxides to allow for more accurate comparisons. Quantities or relative concentration of the material from which a sample is extracted will be provided.

Rheological data from the formated slurry and melter feed will be reported in graph format, with apparent viscosity plotted as a function of shear rate. A curve fit with the form discussed in Section 5.1 .2 will be superimposed on the actual data. Data from simulant waste, radioactive waste and TDP values will be combined on graphs to facilitate comparisons. Raw data will be provided in an appendix table.

\subsubsection{Vitrification and Product Testing}

Glass properties data (chemical, physical, and radiochemical) will be reported in table format. The set-up will be similar to the formated slurry and melter feed so as to allow simple comparisons between radioactive and simulant values.

Release rate data from PCT testing will be reported in both table and graph format. Direct comparisons will be made between 1) in-cell radioactive and simulant data, 2) in-cell and out-of-cell simulant data and 3) out-of-cell simulant data and CVS model predictions.

\subsection{END DATA USE}

Data collected by this study will be used to:

1) help verify design assumptions of the hydrogen mitigation system;

2) support claims by the project to the Washington Department of Ecology (WDOE) and Environmental Protection Agency (EPA) relative to ${ }^{129} \mathrm{I},{ }^{4} \mathrm{C}$, and total hydrocarbon releases;

3) help verify design parameters of the HWVP design;

4) provide a comparison of simulant to radioactive waste properties data;

5) provide a comparison of simulant waste properties correlations to radioactive data;

6) relate radioactive glass properties to models predictions (i.e., (VS); and

7) provide data for the WFQ Report.

The end-use of each piece of data. is indicated in Tables 4.3, 4.4, and 4.6 through 4.9. 


\subsection{ENVIRONMENTAL SAFETY AND HEALTH (ES\&H), WASTE MANAGEMENT REQUIREMENTS, AND QUALITY ASSURANCE}

\subsection{SAFETY}

Testing operations will be performed according to this approved test plan, approved test instructions, PNL-MA-43 "Industrial Hygiene, Occupational Safety and "Fire Protection Programs", and specific safety requirements for the 324 and 325 Building facilities. Testing operations involving the use of formic acid will be performed according to specific requirements included in Technical Procedure WTC-053-2 "Procedure for Treating Slurries with Formic Acid, Adding Glass Frit and Drying the Slurry for Vitrification." Testing operations involving the use of nitric acid will be performed according to specific requirements included in the test instructions for leach testing of radioactive and nonradioactive glass.

\subsection{WASTE DISPOSAL}

A11 waste generated by this program shall be disposed of in a manner consistent with PNL-MA-8, Waste Management and Environmental Compliance, which is consistent with local, state and federal regulations. The wastes to be generated during this study include analytical samples, failed equipment, cleaning materials, solid containers (i.e., beakers, centrifuge cones, pipets, crucibles, etc.) contaminated by residual waste, etc. The actual core sample waste will be converted into glass, tested and archived.

Type $A$ and Type $B$ quantities of radioactive mixed waste are anticipated as a result of this study. Currently, Type $B$ quantities cannot be disposed of, although the problem is being worked. The Safety Analysis Review (SAR) for the central waste complex should be completed in February 1992 and Type B quantity disposal should be allowed starting March 1992. Alternatively, our Type $B$ quantities may be reduced to Type $A$ quantities with additional cleaning effort. In either case, this study will not commence until a PNL waste management specialist has reviewed the quantities and types of waste expected to be generated and verifies that proper storage and disposal methods are known and can be implemented. 
The Preliminary Environmental Checklist is contained in the appendix. The PNL Small Quantity Treatability Test Standards Approval Form is contained in the appendix. The Treatability Study Tracking System form to be used for the vitrification study hazardous materials monitoring is included in the appendix.

\subsection{QUALITY ASSURANCE}

The RPPLT has been designated as QA Impact Level I for activities relating to glass and leachate characterization and Impact Level II for remaining activities under the PHTD quality assurance plan WTC-006 (latest Rev.). All data records, calculations, and analyses reported from this test will be documented in a sufficient manner to be traceable from the primary data and the methods and equipment used, through the assumptions and/or interpretations made, to the corresponding results reported in the final report.

Samples and analytical work will be tracked using the Analytical Request Form (ARF). Calibrated measuring and test equipment (M\&TE) will be used for data reported to support design and WFQ to assure that accuracy and reliability of the reported data can be substantiated. Data obtained for preliminary study or to assist in the main operation may include data obtained by uncalibrated instrumentation, but will be identified as such. Current lists of M\&TE will be maintained in accordance with PAP-70-1701.

Data from the RPPLT will be collected on test instructions, data sheets, status log sheets, DOS files, and in laboratory record books (LRBs). Data will be reviewed by an engineer or scientist (other than the generator) prior to reporting.

Project records pertaining to this work will be maintained in records inventory and disposition schedule (RIDS) in accordance with PAP-70-1201.

Changes affecting the objectives of the testing program identified in this test plan shall be reviewed and approved by appropriate PHTD personnel. The significance of the changes shall be determined by the cost account manager. Major changes, such as changes to program objectives, will be 
documented by issuing a revision to the test plan. Minor changes will be made by mark up of issued copies of the current revision (work place copy at a minimum). All minor changes shall be signed and dated by the cognizant engineer.

Technical procedures will be used to support a variety of repetitive activities (e.g., physical and rheological measurements, formic acid addition, frit addition, leach testing) during this test. These procedures will be prepared in accordance with PAP-70-1101 and will be approved before the start of the test. Other non-repetitive activities, which are defined and controlled by this test plan may be performed according to detailed test instructions. These test instructions will be prepared and approved before the start of the test. 
PHTD-C92-05.05A

\subsection{REFERENCES}

Allen, C. R. 1990. Fiscal Year 1990 Status, Vitrification and Characterization of Radioactive Core Samples, 101-AZ Core \#1 and 101-AZ Core \#2. Letter Report to Westinghouse Hanford Company, Prepared by Pacific Northwest Laboratory, Richland, Washington.

Cecille, L. and S. Halasovich, ed. 1986. Denitration of Radioactive Liquid Waste.

Elliott, M. L., E. V. Morrey and J. M. Tingey. 1991. Status Letter on Radioactive Formating, Vitrification, and Product Testing. Letter Report to Westinghouse Hanford Company, Prepared by Pacific Northwest Laboratory, Richland, Washington.

Gibson, M. W. and B. C. Landeene. 1987. Flowsheet Computer Simulation for Demonstration of NCAW Pretreatment at B Plant. SD-RE.TI-190, Rev. 0, Westinghouse Hanford Company, Richland, Washington.

Goles, R. W. and R. K. Nakaoka. 1990, Hanford Waste Vitrification Program Pilot-Scale Ceramic Melter Test 23, HWVP-89-IVJ0010100B.

Gray, W. J., M. E. Peterson, R. D. Scheele, and J. M. Tingey. 1991. Characterization of the First Core Sample of Neutralized Current Acid Waste from Double-Shel1 Tank 102-AZ. Letter Report to Westinghouse Hanford Company, Prepared by Pacific Northwest Laboratory, Richland, Washington.

Hutson, N. D., J. R. Zamecnik, M. E. Smith, E. H Miller, J. A. Ritter, Integrated DWPF Melter System (IDMS) Campaign Report - The First Two Noble Metal Operations. Westinghouse Savanah River Company, Aiken, South Carlina, 6 June 1991. WSRC-TR-91-0400.

Larson, D. E. 1989. Hanford Waste Vitrification Plant Technical Manual, HWVP89-1VJ0010100A. Prepared by Pacific Northwest Laboratory, Richland, Washington.

Longstaff, J. V. and K. J. Singer. 1954. J. Chem. Soc. 2610.

Wiemers, K. D. 1990. The Effect of HWVP Feed Nitrate and Carbonate Content on Glass Redox Adjustment, Letter Report to Westinghouse Hanford Company, HWVP-90-1.2.2.03.03A, Prepared by Pacific Northwest Laboratory, Richland, Washington.

Wiemers, K. D., C. A. Anderson, and M. E. Peterson. 1987. Evaluation of Process off-Gases Released During the Formating of an HWVP Feed Simulant, Letter Report to Westinghouse Hanford Company, HWVP-86-V110203G, Prepared by Pacific Northwest Laboratory, Richland, Washington.

Wiemers, K. D., M. A. Langowski, and M. R. Powell. 1991. Detailed Design Data Package - Draft, PHTD Redox/Rheology Evaluation Control Cost Account, 
PHTD-C92-05.05A

APPENDIX 
PHTD-C92-05.05A

PRELIMINARY ENVIRONMEITAL CHECKLIST

OROLECT MAUE/MUYBER HWUP NTQQ/15437

Respond to each question with a "yes" or "no" for the proposed activity. Consider potential significant environmental impacts during BOTH the construction and operational phases of the proposed activity.

will the proposed projest/activity:

Yes . No

1. result in use, generation", handling, storage, disposal, or transportation of liquid or solita materials that contain hazardous(a) and/or radioactive - consituents?

2. require use of carcinogens, pesticides or toxic substances or large quantities of oil?

3. result in ANY gaseous or particulate reiesse to the environment which might contain hazirfous and/or radioactive constituencs?

4. result in ANY liquid release to the environmerit which might contain hazardous and/or radioactive constituents?

三. result in any liquid reiease to uther tian an aooroved liquid disposal system?

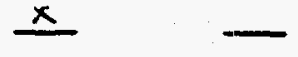

6. result in any soil movement, excavation or suriace alterations?

If any of the responses are "yes," attach a brief written explanation of the project. Include information that would further explain any potential impacts to the environment. Submit the completed form to the Waste Management $\&$ Environmental Compliance (WM\&EC) section (R. L. Newell, M/S P7-68, 376-3835) in the Laboratory Safety Department. The wM\&E stafi will review the checklist and other information to deremine if any additional NEPA documentation will be required.

Reviewed by

Laboratory Safety Department:
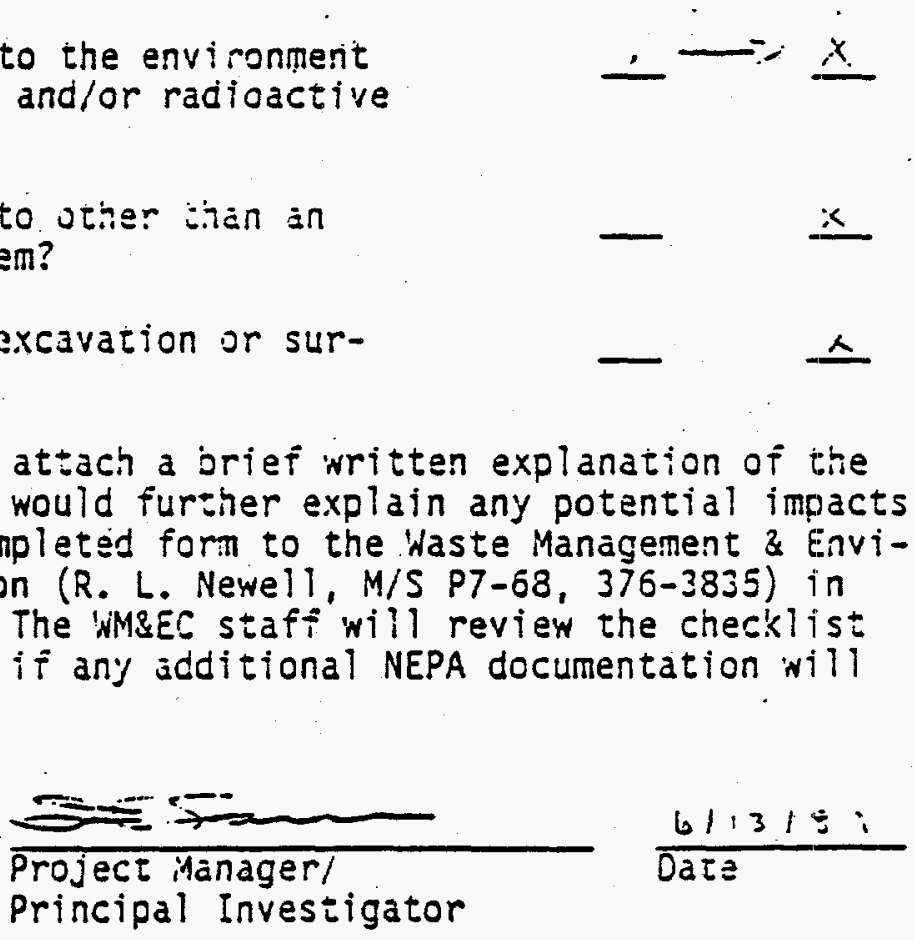

\begin{abstract}
required.
\end{abstract}
(2) 


\section{PRELIMINARY ENVIRONMENTAL CHECKLIST EXPLANATION}

The test program covered by this test plan involves converting synthetic nonradioactive neutralized high level waste (HLW) and radioactive neutralized HLW into glass using the vitrification process as a laboratory verification of the process. The nonradioactive and radioactive laboratory programs will be performed in the laboratory and hot cell facilities respectively as identified in the test plan. The facilities and test procedures to be used for the test programs are designed to assure compliance with Pacific Northwest laboratory and other applicable regulations. Similar laboratory studies are currently being performed in the facilities to be used. 
PAII RCRA SWLIII QUANTITY TREATABIIITS IEST ST.LVDARDS APPROVAI FORYI

\section{Lacoratory Sarey Departrenters}

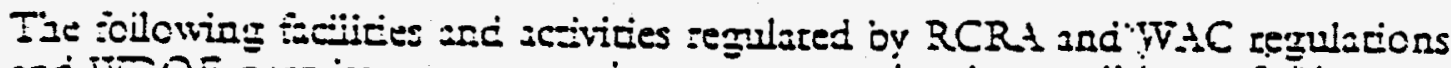

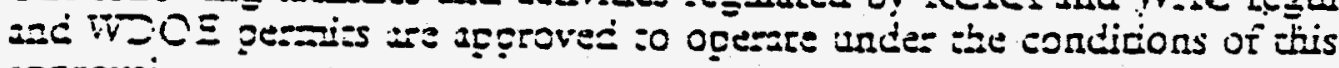
segrovici.

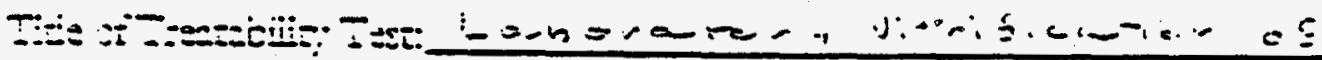

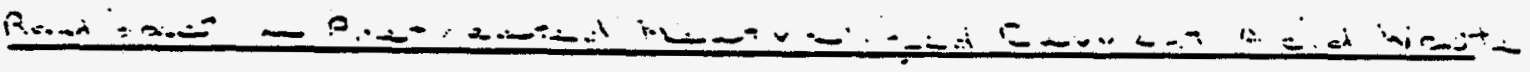

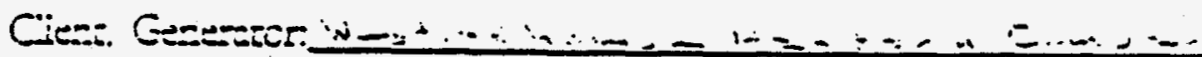

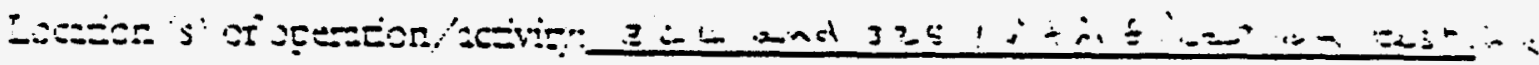

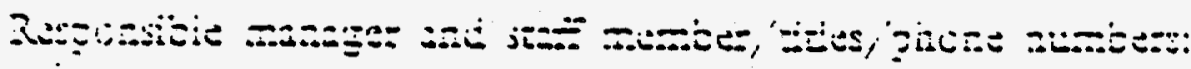

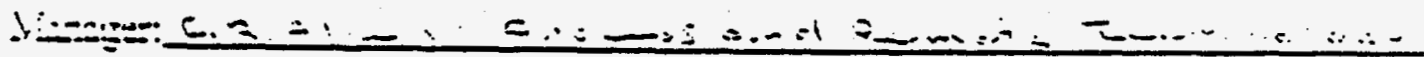

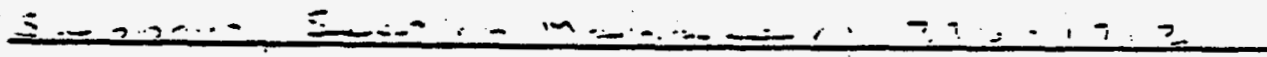

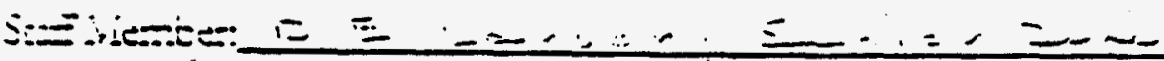
$E_{n=\ldots}-\ldots, \cdots, \cdots$,

Pascististorou:

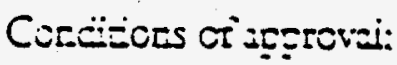

Signarories:

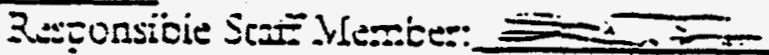

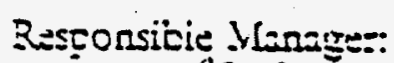



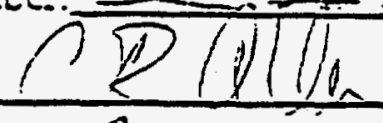

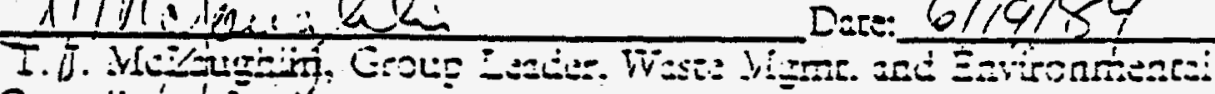
Cormiiticé severcs

Licoraror: Sarton Dearment 


\section{Laboratory Safely Department \\ TREATABILITY STUDY TRACKING SYSTEM (TSTS) \\ Universal Form No.-TSTSO1, ver. 1, 3/89}

This is a universal form to be used by all PNL hazardous waste treatability test researchers to report their activities to Laboratory Safety Department. The original of this form should be retained by the researcher. It is recognized that the researcher will be able to answer various parts of this form at different times during testing of wastes. As information becomes available to the researcher, the appropriate blanks in this form should be completed, the form copied and sent to M.W. McCoy at P7-68 (376-1483). All test data will be maintained in Laboratory Safety Department and regular reports made to the state of Washington. Each researcher must relain copies of all test records for 3 years.

Note: Questions printed in BOLD letters will be completed by Laboratory Safety Department

\section{PROJECT}

1. Project Name:

2. Project No.: 3. Researcher's name:

4. Researcher's bldg., room, mail stop, telephone no.:

\section{WASTE}

5. Description of waste:

6. Waste generator:

7. Generator's EPA-ID no.: 8. Date waste shipped:

9. Date waste received: 10. Method of shipment:

11. Waste storage location - bldg. and room:

12. Date waste returned to generator $L$ ) or TSD facility $L$ [check one]:

13. If sent to TSD facility, give name of facility: 
14. Method of shipment: 15. Waste ID No.:

16. Waste quantity (kilograms): 17. Waste Stream:

18. Waste classification:

IEST

19. Test planned (technology):

20. Weight of waste tested:

21. Test Date:

Note: Inform Laboratory Safely Department at least one week prior to any test. 22. Tesi location: 23. Test completion date:

24. Post-test waste wt. (kg.): 25. Post-iest residue wt. (kg.):

26. Residue classification (dangerous, ext. haz.):

27. Residue classification performed by [method and person(s)/lab]:

28. Final disposition of waste and any generated residue:

Researcher (signature)

Form transmittal dates:

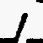
1

(The date copies of this form transmitted to Laboratory Salety Department) 